WORKING PAPER \#625

PRINCETON UNIVERSITY

INDUSTRIAL RELATIONS SECTION

FEBRUARY 2019

http://arks.princeton.edu/ark:/88435/dsp01wd376007f

\title{
The Impact of Privatization of State-Owned Enterprises on Workers*
}

\author{
David Arnold ${ }^{\dagger}$
}

February 6, 2019

\begin{abstract}
I study the impact of privatization of state-owned enterprises (SOEs) on workers at privatized SOEs and on the aggregate labor market. Using a matched employer-employee dataset, I find privatization in Brazil between 1996-2000 lowered incumbent workers' wages by a substantial 30 log points relative to a matched control group. Half of this decline is due to privatized workers facing an increased risk of displacement and moving to lower-paying establishments, while half is due to within-establishment wage changes. The direct impacts understate the total cost of privatization to workers in the presence of general equilibrium spillovers. To estimate spillovers on private-sector labor markets, I construct an exposure to privatization measure that depends on the transition probability between jobs in a given labor market and jobs in privatized SOEs. I find wages decline in labor markets that are more exposed to privatization relative to those that are less exposed. A summary calculation suggests that privatization decreased the aggregate wage in the formal sector of the Brazilian labor market by 4.5 log points, with about one-quarter of this effect attributable to the direct effect on privatized workers and three-quarters attributable to spillovers.
\end{abstract}

*I thank Leah Boustan, Will Dobbie, Henry Farber, David Lee, Hani Mansour, Maurício Matsumoto, Alexandre Mas, Christopher Neilson, Isaac Sorkin, Owen Zidar and numerous seminar participants for helpful comments and suggestions.

${ }^{\dagger}$ Princeton University. Email: dharnold@ princeton.edu 


\section{Introduction}

State-owned enterprises (SOEs) employ about 2 percent of all workers in OECD countries, with a substantially higher proportion in many developing countries (Subramanian and Megginson, 2018). Given the value of SOEs in many countries, privatization remains a popular policy tool for debt-burdened governments to quickly raise large amounts of revenue ${ }^{1}$ For example, in 2018, former Brazilian president Michal Temer introduced a privatization program to sell 57 state-owned assets, including Eletrobras, the largest power utility company in Latin America. Supporters of the privatization program argue that privatization will both raise revenue for the government as well as improve the efficiency of firms. At the same time, workers and trade unions have organized multiple protests, fearing privatization will lower wages and employment $2^{2}$ Despite worker and union fears, there is little direct evidence on the impact of privatization on worker outcomes.

This paper studies both the direct impact of privatization on incumbent workers in privatized SOEs as well as the broader labor market impacts of privatization activity. Given the scope of privatization in many countries, large reductions in employment at privatized SOEs will increase the supply of workers to privatesector firms, resulting in lower equilibrium wages. To estimate both the direct impacts and spillovers, I utilize a matched employer-employee dataset which contains information on all formal-sector workers in Brazil. The identification strategy makes use of Brazil's 1990s privatization program which privatized about 3 percent of all formal-sector employment in Brazil $S^{3}$ To identify spillovers, I construct a measure of exposure to privatization at the occupation-by-region level which traces how the impacts of privatization propagate through firms in labor markets connected to privatized SOEs by labor mobility.

In the first part of the paper, I estimate the impact of privatization on incumbent workers in privatized SOEs. To do so, I construct a control group using a coarsened-exact-matching algorithm (CEM) to match privatized workers to similar workers in private-sector establishments or never-privatized SOEs. I find that while wages experienced similar trends in the years prior to privatization, wages fall by $30 \log$ points in the long run among privatized workers following privatization $\sqrt[4]{4}$ The large decline in earnings is due to two separate effects. First, workers displaced by privatization move to lower-paying establishments. Second, workers who remain employed at the privatized SOEs experience wage reductions relative to control workers. In order to decompose the effect on wages, I estimate the impact of privatization for workers who stay within the same establishment in the years following privatization. I find that wages for establishment stayers fall by about 17 log points in the long run, implying that roughly half of the wage decline for privatized workers is due to a displacement effect, while half is due to within-establishment changes in compensation policies.

In the second part of the paper, I consider the impact of privatization on establishment-level employ-

\footnotetext{
${ }^{1}$ In 2015, privatization revenues peaked at over 300 billion USD (Megginson, 2017).

${ }^{2}$ See markets.businessinsider.com/news/interestrates/eletrobras-workers-hold-72-hour-strike-1026878928

${ }^{3}$ Author's calculation. As will be discussed in Section II this paper restricts analysis to privatization events which occur between 1996-2000. A number of large SOEs were privatized in the early 1990s in Brazil. Therefore, the number cited understates the total number of workers directly impacted by privatization in Brazil in the 1990s.

${ }^{4}$ This analysis excludes observations with zero earnings as Brazil has a large informal sector (40 percent) and therefore years of zero earnings in the administrative data are not indicative of unemployment for many workers. However, I do find workers in SOEs are 10 percentage points less likely to be working in the formal sector following privatization, suggesting the results using only positive earnings is likely a lower bound.
} 
ment. While the worker-level analysis finds privatized workers are more likely to be displaced than control workers, privatized SOEs may increase hiring so that total employment is unchanged 5 Understanding how privatization affects establishment-level employment is important for predicting how privatization will impact workers in private-sector firms. For example, if privatized SOEs replace entrenched workers with new hires from the private sector, then privatization may expand job opportunities to private-sector workers. Alternatively, privatization could result in permanent declines in employment which would increase the supply of workers to the private sector and lower equilibrium wages. To identify the impact on establishmentlevel employment, I use the fact that privatization occurred gradually over a number of years (1996-2000). Comparing privatized SOEs to SOEs that will be privatized at a later date, I find employment in privatized establishments falls by about 34 percent following privatization. Therefore, together with the worker-level analysis, this implies privatized SOEs shed incumbent workers and do not replace these workers through increased hiring.

In the last part of the paper, I explore whether these large negative impacts on privatized SOEs spillover to other firms in the same labor market. Theoretically, these spillovers may arise for three reasons. First, given the local nature of the industries impacted (e.g. banking, electricity, telecommunications), changes in product-market competition due to privatization may impact labor demand. Second, large declines in employment at SOEs will increase the supply of workers to private-sector firms, again reducing the equilibrium wage in the private sector. Third, in many models of wage determination (Abowd and Lemieux. 1993 , Pissarides, 2000; Postel-Vinay and Robin, 2002; Hornstein et al., 2011; Card et al., 2018; Kline et al., 2018), the wage paid to a worker depends on the outside option of the worker. Decreases in employment and wages at privatized SOEs lowers the expected value of the outside option for private-sector workers, resulting in lower equilibrium wages.

To identify general equilibrium spillovers, I construct a measure of exposure to privatization at the labor market level. I follow Azar, Marinescu and Steinbaum (2017) and define a labor market as an occupationby-region cell. While defined at the occupation-by-region level, the exposure measure depends on both the fraction of jobs privatized within the occupation-by-region cell, as well as the fraction of jobs privatized in closely related occupation-by-region cells, where two occupation-by-region cells are closely related if workers commonly transition between them. More formally, I define the distance between labor market $i$ and labor market $j$ as the probability a worker from labor market $i$ transitions to labor market $j$ conditional on a job transition. The exposure to privatization of labor market $i$ is equal to the fraction of workers privatized in labor market $i$ plus the fraction of workers privatized in all other labor markets, weighted by the distance between labor markets 6

I find wages fall in labor markets that are more exposed to privatization relative to labor markets that are less exposed to privatization. For example, moving from three percent of the labor market being privatized (the average level across all labor markets) to eight percent of the labor market being privatized (roughly one

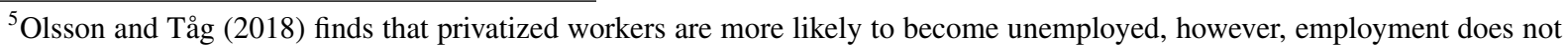
fall at privatized firms, implying that privatized SOEs increase hiring to replace workers displaced during privatization in Sweden.

${ }^{6}$ To ensure the maximum exposure measure sums to 1 , the fraction of workers privatized in labor market $i$ is weighted by the fraction of workers in labor market $i$ who transition jobs, but stay within labor market $i$. For example, if 100 percent of electrical technician jobs in a region are privatized, the exposure measure will not necessarily be equal to 1 , because electrical technicians may transition into other types of jobs that were not directly impacted by privatization. 
standard deviation) is associated with an average market wage decline of roughly $1.6 \log$ points. This analysis excludes all observations from privatized SOEs and therefore does not incorporate any direct impacts of privatization. To quantify the total impact of privatization on the labor market, I perform a simple backof-the-envelope calculation. Conceptually, the calculation computes counterfactual wages for all workers in 1995 (the year prior to the first privatization events studied in this paper) using the event-study estimates, assuming the long-run impact of privatization occurs immediately in 1995. I find the direct impacts (i.e. the effect on workers in privatized SOEs) predicts an aggregate wage decline of about 1.1 log points. Incorporating spillovers magnifies the direct impact and results in an aggregate wage decline of about 4.5 log points. Therefore, in this case, incorporating spillovers is an essential component in estimating the total impact of privatization on workers. While the direct impacts are large, they impact relatively few workers. Spillovers, on the other hand, impact a much larger fraction of workers in the economy.

This paper contributes to a number of distinct literatures. First, it contributes to the long literature on the impacts of privatization on firm profits and efficiency (Boycko, Shleifer and Vishny, 1997; La Porta and Lopez-de Silanes, 1999; Megginson and Netter, 2001; Chong and Lopez de Silanes, 2005; Megginson, 2017). These studies generally find that many measures of profitability increase following privatization. In the particular case of Brazil, Anuatti-Neto, Barossi-Filho, De Carvalho and Macedo (2003) find that return on assets, return on equity, and sales all rise more in privatized firms relative to private-sector firms following privatization. While most papers studying privatization utilize firm-level financial data, two notable exceptions are Firpo and Gonzaga (2010) and Olsson and Tåg (2018), both of which use worker-level data and study the impacts of privatization on workers. To my knowledge, this is the first paper to consider not only the direct impact on incumbent workers, but also the broader labor market impacts of privatization.

The method used to identify spillovers in this paper is similar in spirit to prior work that empirically estimates spillovers in response to firm-level shocks. For example, Bloom, Schankerman and Van Reenen (2013) estimate R\&D knowledge spillovers by creating measures of a firm's position in both product space and technology space. Lane (2017) studies the spillovers related to "big-push" industrial policies in South Korea by constructing measures of exposure to the policy using the sectoral input-output network. A number of studies estimate productivity spillovers due to agglomeration (Rosenthal and Strange, 2004; Moretti, 2011). Similarly, this paper uses a measure of distance in the labor market based on empirical worker flows in order to construct a measure of exposure to privatization.

Lastly, a recent literature documents significant wage dispersion across firms (Card et al., 2013; Barth et al., 2016, Song et al., Forthcoming), even after controlling flexibly for worker quality. This significant dispersion is inconsistent with models of perfect competition and suggests labor market frictions may be important components in understanding the aggregate wage distribution. I find that SOEs pay significant wage premiums over private-sector firms. However, this wage premium declines significantly following privatization, suggesting that differential rent-sharing between SOEs and private-sector firms drives the dramatic decline in earnings in privatized SOEs following privatization.

The structure of the paper is as follows. Section II discusses the institutional details and data. Section III presents a model of privatization that illustrates the channels through which privatization impacts workers. Section IV presents event studies that estimate the impact of privatization on incumbent workers in privatized 
SOEs. Section $\mathrm{V}$ presents event studies that estimate the impact of privatization on establishment-level wages and employment. Section $\mathrm{VI}$ estimates general equilibrium spillovers associated with privatization and Section VII concludes.

\section{Institutions and Data}

\section{A. Privatization in Brazil}

In Brazil, SOEs played a fundamental role in the government's economic development goals. The government of Brazil invested heavily in a number of strategic industries, including mining, steel, chemicals, banking, telecommunications, and electricity. However, in the late 1980s, large fiscal debts led Brazil to sell a number of SOEs as a means to raise revenue. The privatization program began in 1991 with the federal government selling large federal SOEs. Similar programs were enacted at the state-level beginning in 1996. Due to data limitations which will be discussed further below, this paper restricts the analysis to privatization events occurring after 1995 and therefore will exclude many privatization events of the federal program. Given these data restrictions, the primary industries studied in this paper are telecommunications, electricity, and banking 7

All of the primary industries in the sample were only partially privatized. For example, while many banks were sold as part of the privatization process, the Bank of Brazil was considered an important Brazilian institution and deemed politically infeasible to privatize (Firpo and Gonzaga, 2010). In order to determine which firms would be sold, a privatization committee was formed. After choosing the list of proposed companies, the Brazilian Development Bank (BNDES) hired two private consulting companies to value the SOEs that would be sold and to determine an acceptable minimum price. A public auction would then be held, and the enterprise would be sold as long as the minimum acceptable price was reached. In the early 1990s, restrictions were placed on foreign investment, but these restrictions were later relaxed before the period of privatization (post 1994) studied in this paper.

The privatization program was part of broader market reforms. Perhaps the most important reform involved a large trade liberalization program that started in 1988 and ended in 1994. Many studies (MenezesFilho and Muendler, 2011; Kovak, 2013) have found that trade liberalization in Brazil had important impacts on workers' wages. However, all privatization events studied in this paper occur after the end of the trade liberalization. Additionally, to bias the results, trade liberalization would have to differentially impact privatized SOEs and private-sector firms within the same industry. It is unclear why firms in the same industry would be differentially impacted, but in any case, these differences would be evident in differential pretrends between privatized SOEs and control establishments. As will be shown in Section IV] I find no differential pre-trends between privatized workers and a matched control group.

\footnotetext{
${ }^{7}$ The Brazilian government sold Vale mining in 1997 which is currently the largest producer of iron ore and nickel in the world. This privatization event is also included, though the number of workers impacted is less than three percent of the total sample.
} 


\section{B. Data}

The analysis utilizes administrative data from the Relação Anual de Informações Sociais (RAIS) for the years 1992 to 2010. The RAIS data contain linked employer-employee records from a mandatory survey administered by the Brazilian Ministry of Labor and Employment (MTE). Fines are levied on firms that provide inaccurate or incomplete information on the survey. Brazil, however, does have a large informal sector that accounts for about 40 percent of all employment. Therefore, periods of zero earnings do not necessarily indicate unemployment. In Section IV] I discuss how the informal sector impacts the interpretation of the results.

Each entry in the RAIS dataset is an employee-employer match. Each individual and establishment are assigned unique administrative identifiers that do not change over time. Demographic data includes workerlevel variables such as education, gender, ethnicity, and age. The data also include information about the job, such as occupation, tenure, wage, hours, type of labor contract, whether the job has ended, and why the job has ended. Lastly, the data includes establishment-level information, including region and industry.

Most importantly for this study, the RAIS contains data on the legal nature of the establishment. SOEs and private-sector establishments are assigned different codes. When an establishment is privatized, the legal nature of the establishment changes from state-owned to private, but the tax identifier of the establishment does not change (Firpo and Gonzaga, 2010; Muendler, Rauch and Tocoian, 2012). Therefore, privatization events can be identified at the establishment level by tracking when legal codes change from year to year 8 However, the legal nature variable is only available from 1995 onwards. Therefore, only privatization events after 1995 can be identified in the RAIS data.

Occupational classifications in the RAIS follow the $C B O$ (Classificação Brasilieira de Ocupações). The classification system contains 2,355 categories. As part of the identification strategy, I construct a control group by matching privatized SOE workers to workers in the same two-digit occupation, therefore reducing the dimensionality of the occupational classification system and allowing for more matches. Industries are reported under the CNAE four-digit classification (Classificação Nacional de Atividade Econômica) for 654 industries. Again, when matching, I match workers in privatized SOEs to workers in the same two-digit industry. However, as will be discussed further later, matching strategies using more narrow definitions of occupation and industries yield similar results.

\section{Sample Selection}

I restrict attention to workers age 18-65 working in full-time jobs (i.e. at least 35 hours per week). I exclude individuals with invalid identifiers (less than one percent of the data). In the RAIS, the wage is reported in multiples of the monthly minimum wage. The wage refers to total payments, including regular salary payments, holiday bonuses, performance-based and commission bonuses, tips, and profit sharing agreements, divided by total months worked during the year for that employer. To convert this number to real earnings, I use data on the real value of the minimum wage from Brazil's Institute of Applied Economic

\footnotetext{
${ }^{8}$ For a subset of large privatization events, the privatization event and timing is verified in the RAIS. For example, the privatization of the mining company, Vale, was a historic event and documented in the newspapers throughout 1997. I find that Vale's legal identifier changes the year of the privatization event in the RAIS data as well.
} 


\section{Research (IPEA).}

The RAIS dataset includes a variable that indicates the type of employment contract the worker is hired under (e.g. temporary vs. permanent). The most common contract in the data is Consolidação das Leis do Trabalho (CLT) which is the standard full-time employment contract in Brazil. CLT contracts come with government mandated benefits such as severance pay if dismissed without cause. Importantly for this study, workers in SOEs and workers in the private sector are employed under the same legal contract. Therefore, changes in wages and employment due to privatization do not reflect changes in the contract held by workers. In contrast, public administration workers are employed under different contracts and entitled to further benefits, such as employment stabilization policies which limit the state's ability to fire civil servants (Firpo and Gonzaga 2010). However, this project only compares workers in SOEs and workers in private-sector establishments and excludes public administration workers.

\section{Identifying Privatization Events}

As discussed previously, I follow Firpo and Gonzaga (2010) and identify privatization events by identifying when the legal nature of an establishment changes 9 However, before 1995, legal nature is not included in the RAIS data, making it impossible to infer privatization events from changes in the legal nature variable. Therefore, this paper restricts analysis only to privatization events occurring from 1996-2000 10 In Figure 1 . I plot the number of workers currently employed in privatized establishments during each year of privatization in the sample. As can be seen in Figure 1, from 1996 to 2000, around 900,000 workers are employed in privatized establishments. Overall, this corresponds to about 3 percent of all formal sector employment. ${ }^{11}$

\section{E. Do SOEs Pay Higher Wages?}

Before considering the effect of privatization on wages, I first establish that there is a significant wage premium associated with working for an SOE before privatization occurs. To do so, I estimate a two-way fixed effects model with worker and establishment fixed effects following Abowd, Kramarz and Margolis (1999) (AKM) and Card, Heining and Kline (2013) utilizing data from the years prior to the privatization (1992-1995) ${ }^{12}$ Formally, I estimate the following regression model:

$$
\ln \left(w_{i t}\right)=\alpha_{i}+\psi_{J(i, t)}+\gamma_{t}+x_{i t}^{\prime} \beta
$$

where $\alpha_{i}$ is an individual fixed effect, $\psi_{j}$ is an establishment fixed effect, $\gamma_{t}$ is a year indicator, $x_{i t}^{\prime}$ are timevarying covariates which include education and an age cubic interacted with year indicators, and $J(i, t)$ is a function which indicates the establishment individual $i$ is employed at in time period $t$. Given the

\footnotetext{
${ }^{9}$ In some cases, the legal nature of an establishment changes and then immediately reverts back in the following year. As in Firpo and Gonzaga (2010), I only include privatization events in which the legal nature switches from SOE to private-sector and the establishment remains in the private-sector in all following years of operation.

${ }^{10}$ While there are a few privatization events after 2000, Brazil's privatization stalled significantly around 2000.

${ }^{11}$ Note that this number understates the total number of workers impacted by privatization in Brazil because it does not include any of the privatization events which occurred prior to 1996.

${ }^{12}$ Instead of estimating an AKM model which relies on transitions between establishments, one could instead estimate a wage premium by regressing wages on a list of controls. Regressing wages on education, age, tenure, occupation fixed effects, industry fixed effects, and an indicator for working in an SOE yields a wage premium associated with working in an SOE of 22 log points.
} 
individual fixed effects, the establishment-specific wage premium $\psi_{j}$ is interpreted as the premium paid by establishment $j$ controlling for the quality of workers employed at establishment $j$. As discussed in Card et al. (2013) and Card et al. (2018), $\psi_{j}$ is only identified relative to an omitted establishment. In practice, I omit the largest private-sector establishment when estimating the AKM model.

For the estimation to yield an unbiased estimate of $\psi_{j}$, the "exogenous mobility" assumption must be satisfied. This assumption allows high-wage workers to sort to high-wage establishments but does not allow workers to sort based on idiosyncratic match effects. This implies firms offer a proportional wage premium to all workers regardless of their skill level and job. While a restrictive assumption in theory, it appears to hold in many contexts (Card et al., 2013; Song et al., Forthcoming), and in particular, in Brazil (Alvarez, Benguria, Engbom and Moser, 2018) 13

I estimate Equation (1) on the entire sample of establishments and collect the estimated $\hat{\psi}_{j}$ for all firms ${ }^{14}$ I then make two sample restrictions. First, I restrict the sample to the primary privatized industries which includes banking, telecommunications, and electricity. Second, to focus analysis on privatized SOEs, I exclude SOEs that are never privatized ${ }^{15}$ To estimate the wage premium associated with a privatized establishment prior to privatization, I estimate the following regression:

$$
\hat{\psi}_{j}=\alpha+\omega \text { Privatized }_{j}+\xi_{j}
$$

Where $\xi_{j}$ are industry fixed effects. Therefore, this regression compares the wage premium of SOEs that will become privatized at a later date to private-sector establishments that employ workers in the same industry. Following the AKM literature, the regression is performed at the worker level and therefore gives more weight to larger establishments. In this specification, $\hat{\omega}$ is equal to the wage premium associated with privatized establishments.

As can be seen in Table 1, on average, the establishment effect for SOEs is $23.1 \mathrm{log}$ points higher in SOEs relative to private-sector establishments. There is a consistent wage premium across the main industries associated with privatization. The lowest wage premium (14.1 log points) is associated with banking while the largest wage premium (49.2 log points) is associated with telecommunications. One important caveat to this estimation procedure is that I identify establishments as private-sector based on their legal nature in 1995. Therefore, it is possible that I identify some privatized SOEs as private, given I can only identify privatization events after 1995. Therefore, in theory, $\omega$ may be underestimated given some establishments identified as private may not have been private over the entire estimation period.

This analysis provides the first evidence that even conditioning on worker quality, SOEs pay higher wages. If the large wage premium is due to differential rent-sharing between workers and firms at SOEs relative to private-sector firms, then this could explain why unions and workers fear privatization will lead to lower wages for workers.

\footnotetext{
${ }^{13}$ Card et al. 2013) offers a number of tests aimed at validating the AKM model assumptions. (Alvarez et al. 2018) replicates these tests in Brazil.

${ }^{14}$ As discussed in length in Card et al. (2018), the AKM model is only identified on a set of establishments connected by labor mobility. In practice, I restrict the sample to the largest connected set.

${ }^{15}$ The wage premium associated with the never-privatized SOEs is similar to the wage premium associated with privatized SOEs.
} 


\section{Model of Privatization}

\section{A. Overview}

Before proceeding to the empirical analysis, I present a simple model of state-owned enterprises to illustrate channels through which privatization may impact workers. This model builds from the union-wage determination models illustrated in Brown and Ashenfelter (1986) and Abowd and Lemieux (1993). In the model, increases in productivity due to privatization will increase wages, while decreases in bargaining power will reduce wages. The model also clarifies how privatization spills over to private-sector establishments.

\section{B. Setup}

To begin, I consider a group of $\bar{L}_{j}$ workers bargaining over both wages and employment level with a firm of type $j \in\{$ soe, $p\}$, where soe denotes an SOE and $p$ indicates a private-sector firm. The workers seek to maximize $L_{j} w_{j}+\left(\bar{L}_{j}-L_{j}\right) v$, where $w_{j}$ is the bargained wage, $L_{j}$ is the employment level, and $v$ is the value of the outside option to the workers. In this case, I assume workers who do not obtain employment reenter the labor force and search for a new job. Therefore, the value of the outside option is equal to the expected wage of the new job minus any search costs $c$ associated with finding a new job.

The workers bargain with a firm that has a concave production function $F\left(L_{j}\right)$, where the production function is constant across SOEs and private-sector establishments ${ }^{16}$ The profits of a firm are given by $\theta_{j} F\left(L_{j}\right)-w_{j} L_{j}$, where $\theta_{j}$ is a revenue shifter. For example, if the firm becomes more efficient, or the demand for the firm's good increases, then these changes will be captured by an increase in $\theta_{j}$. I assume workers and firms Nash-bargain over wages, where the bargaining weight associated with labor is given by $\gamma_{j}$, which is allowed to differ between SOEs and private-sector firms. If $\gamma_{s o e}>\gamma_{p}$ then SOEs allocate more rents to labor than private-sector firms.

The threat point for workers is the value of the workers' outside option, while the threat point for the firm is zero profits. SOEs, in addition to profits, may also receive additional revenue per worker, $\tau_{j}$. For simplicity, I assume $\tau_{\text {soe }}>0$ and $\tau_{p}=0$, capturing the idea that politically connected firms may receive preferential treatment (Khwaja and Mian, 2005). Alternatively, one may conceptualize $\tau_{\text {soe }}$ as arising from political pressure and not directly from cash transfers. The parameter is included to capture any additional benefit of employment for an SOE above and beyond a worker's output. The bargaining solution chooses $L_{j}$ and $w_{j}$ to maximize:

$$
\max _{L_{j}, w_{j}}\left[L_{j} w_{j}+\left(\bar{L}-L_{j}\right) v-\bar{L} v\right]^{\gamma_{j}}\left[\theta_{j} F\left(L_{j}\right)+\tau_{j} L_{j}-w_{j} L_{j}\right]^{1-\gamma_{j}}
$$

Taking the first order conditions for the bargaining problem yields the following two optimality conditions:

$$
w_{j}=\gamma_{j}\left(\frac{\theta_{j} F\left(L_{j}\right)}{L_{j}}+\tau_{j}-v\right)+v
$$

\footnotetext{
${ }^{16}$ While the homogeneity of the production function is not strictly necessary, it simplifies the illustration.
} 


$$
\theta_{j} F^{\prime}\left(L_{j}\right)=v-\tau_{j}
$$

As can be seen in Equation (4), wages will be higher in firms with higher productivity $\theta_{j}$, in firms with more incentives per worker from the state $\tau_{j}$, and when the outside option $v$ is higher. Equation (5) dictates the optimal size of the firm. If $F(L)$ is concave, then conditional on productivity and the outside option available to workers, SOEs will be larger as long as $\tau_{\text {soe }}>0$. By allowing workers and firms to bargain over both wages and employment, the resulting bargaining outcome is strongly efficient (Farber, 1986). This implies that firm size does not depend on the negotiated wage. Restricting firms and workers to bargain over the wage only, however, yields similar predictions regarding the impact of privatization on workers. Therefore, I present only the strongly efficient bargaining solution as it simplifies the illustration.

\section{Effect of Privatization on Workers in Privatized SOEs}

In this formulation, there are three reasons why SOEs would offer higher wages than private-sector firms. First, they could be more productive due to differences in $\theta_{j}$. This would cause SOEs to have both higher wages and higher employment levels, consistent with the empirical facts. Second, as informally argued by unions opposing privatization, the bargaining parameter, $\gamma_{j}$, may differ between SOEs and private-sector firms. Lastly, I allow SOEs to retrieve transfers $\tau_{j}$, which increases the surplus available, some of which gets transferred to workers in the form of higher wages.

Many policy-makers claim that privatization increases efficiency, which can be captured in this model as an increase in $\theta_{j}$. In this model, as in search (Burdett and Mortensen, 1998) and wage-posting models (Kline et al., 2018), firm size and wages are positively correlated with productivity. Therefore, increases in productivity generate increases in both firm size and wages. In contrast, falling incentives per worker, $\tau_{j}$, generate declines in wages and employment, while falling worker bargaining power, $\gamma_{j}$, generates declines in wages ${ }^{17}$

\section{Spillovers on Private-Sector Firms Due to Privatization}

In the model, there are three possible ways in which privatization will spill over to other firms. The first is through a product-market spillover. For example, if privatization changes competition in the product market, this could shift $\theta_{j}$ for private-sector firms, which would then impact wages. In Section VI, I discuss specifications which eliminate product-market spillovers as a channel which allows me to gauge their importance empirically.

A second spillover channel arises in the model due to changes in the outside option $v$, which is defined as the expected wage of a new job minus any search costs associated with finding the job:

$$
v=\mathbb{E}[w]-c=\lambda_{u} b+\lambda_{p} \mathbb{E}[w \mid j=p]+\lambda_{\text {soe }} \mathbb{E}[w \mid j=s o e]-c
$$

where $\lambda_{u}$ is the probability a worker becomes unemployed, $b$ is the value of unemployment, $\lambda_{p}$ is the probability a worker gets a job at a private-sector firm, $\mathbb{E}[w \mid j=p]$ is the expected wage at a private-sector

\footnotetext{
${ }^{17}$ If the strong efficiency assumption is violated, then falling worker bargaining power will generate declines in both wages and employment.
} 
firm, $\lambda_{\text {soe }}$ is the probability a worker gets a job at an SOE and $\mathbb{E}[w \mid j=s o e]$ is the expected wage at an SOE 18

To understand how changes in wages and employment at privatized SOEs spill over to other firms, imagine that privatization decreased only employment at privatized SOEs, but kept wages exactly the same. This would cause $\lambda_{\text {soe }}$ to decrease (i.e. it is now more difficult to get a job at an SOE given employment has fallen at SOEs). This decreases the value of the outside option because it is now less likely a privatesector worker can become employed at a high-wage establishment. A second effect arises if privatized firms decrease wages, holding employment fixed. In this case, the quality of the outside options has decreased, again leading to a decrease in the negotiated wage.

In the model, falling and employment and wages at SOEs impact private-sector workers through the outside option. However, declines in employment at SOEs may impact private-sector workers even in perfectly competitive markets. Workers displaced by SOEs will increase the supply of workers to the private sector, therefore decreasing the equilibrium wage through a labor-supply effect. In this case, as the wage falls, private-sector firms will increase employment to equate marginal revenue product and marginal cost (i.e. the wage). Through the lens of the model, privatization may directly impact $\mathbb{E}[w \mid j=p]$ if privatization increases the supply of workers to private-sector firms. While decomposing the impact of spillovers due to changing outside options and changing labor supply is beyond the scope of this paper, I do provide suggestive evidence that the outside option is at least important in empirically explaining spillovers.

\section{Effect of Privatization on Incumbent Workers}

\section{A. Overview}

The goal of this section is to estimate the effect of privatization on wages and employment for incumbent workers in privatized SOEs. A priori, it is not obvious how privatization will impact wages. As shown in Section [I] workers in SOEs earn higher wages prior to privatization, however, it is not clear whether this stems from differences in unobserved productivity or due to differences in rent-sharing between workers and establishments. To estimate the causal impact of privatization, I utilize a matching algorithm to find a control group for privatized workers and then estimate event studies around the time of privatization.

\section{B. Finding a Control Group}

Workers in SOEs are likely different than the average worker. For one, SOEs are generally larger and produce in industries deemed strategic by the government. Therefore, there might be important differences between workers in SOEs compared to the general population of workers. In order to create a valid control group, I use a matching algorithm to find workers which are in the same occupation, industry, and of similar age. In the main specifications, I allow the control worker to be drawn from either never-privatized SOEs or private-sector establishments. A priori, it seems plausible that either group could be a potentially valid counterfactual and I therefore allow matches to be drawn from either group to increase the likelihood a match

\footnotetext{
${ }^{18}$ As discussed previously, many workers are employed in the informal sector. While the informal sector is not directly accounted for in the model, unemployment can be reinterpreted as a combination of unemployment and informal sector employment.
} 
is found for a given treated worker. However, it is true that workers in never-privatized SOEs and privatesector establishments earn very different wages even conditional on occupation and sector. However, while the levels differ greatly, the trends are similar in practice, and therefore the qualitative results hold regardless of the control group. Appendix A presents additional specifications which restrict the control group to either private-sector workers only or never-privatized SOE workers only.

Before finding the control group, I restrict the treated sample to individuals who are employed a privatized SOE in years $t-1$ and year $t-2$ prior to the privatization event in year $t$. This tenure restriction is chosen in order to limit the analysis to workers with attachment to the establishment. In order to find a control group for workers in a privatization event in year $t$, I first impose the same tenure restriction on private-sector workers and non-privatized SOE workers. Next, I implement a coarsened-exact-matching (CEM) procedure following Iacus et al. (2012). Specifically, the algorithm matches workers exactly on twodigit occupation codes, two-digit industry codes and five-year age bins. In additional results in Appendix A. I add more variables to the matching algorithm, such as establishment size and microregion, as well as match on more specific occupation and industry codes. In all cases I find results to be similar across matching algorithms. The matching algorithm utilized is similar to a number of recent papers (Goldschmidt and Schmieder, 2017; Smith et al., 2017; Jaravel et al., 2018) which estimate event studies with a matched control group.

Table 2 displays the summary statistics for the privatized workers and the control group in the year prior to privatization. The privatized and control workers have similar educational attainment levels (48 percent of privatized workers are high-school graduates while 44 percent of control group workers are highschool graduates). The log monthly wage for privatized workers is slightly higher (8.64) than the control group (8.58). Privatized workers are employed in larger establishments than non-privatized workers (median establishment size in privatized establishments is 765 compared to 416 in the control group). Therefore, matching on occupation, industry, and age does not fully eliminate differences between privatized workers and non-privatized workers. However, the identification strategy relies on parallel trends between privatized workers and non-privatized workers, not complete balance on covariates.

One benefit of the matching approach is that comparing raw averages across groups is a meaningful comparison. Figure 2 plots the average monthly wage for the group of privatized workers and the matched control group. Given workers can transition into unemployment, the informal sector, or out of the labor force, Figure 2 is not restricted to a balanced panel. However, as can be seen in Figure 2, there is a stark divergence in wages following privatization, with the average log monthly wage in the privatized group falling roughly $30.0 \mathrm{log}$ relative to the control group 19

\footnotetext{
${ }^{19}$ In Appendix Figure $\mathrm{A} 1$ and Appendix Table $\mathrm{A} 1$ results for matching algorithms which restrict to only private workers or to only never-privatized SOE workers are displayed. For the private-sector control, wages in the control group are much lower than in the privatized group prior to privatization, consistent with the fact that SOEs pay higher wages even conditional on detailed characteristics. Results which add microregion and establishment size to the list of matching variables are also displayed in Appendix Table A1
} 


\section{Worker-Level Event Studies}

To estimate the effect of privatization on workers' outcomes, I use an event-study framework by estimating regression models of the following form:

$$
y_{i t}=\sum_{k=-4}^{10} \delta_{k}\left(t=t^{*}+k\right) \text { Privatized }_{i}+\alpha_{i}+\gamma_{t}+x_{i t}^{\prime} \beta+\varepsilon_{i t}
$$

where $y_{i t}$ is an outcome variable, Privatized $_{i}=1$ if individual $i$ was employed in an establishment that is privatized, $\alpha_{i}$ are worker fixed effects, $\gamma_{t}$ are time fixed effects, $x_{i t}$ are time-varying worker controls that include a cubic in age, and $\varepsilon_{i t}$ is an error term. Each $\delta_{k}$ measures the change in the outcome variable $\left(y_{i t}\right)$ for the privatized workers relative to the control group in year $k$ relative to the privatization year $t^{*}$. Standard errors are two-way clustered at the individual and establishment level.

There are two key assumptions in estimating Equation (7). First, results in Table 2 show that the matched control group is similar but not identical to the privatized workers group. If workers in the privatized group have differential wage trends, then I will incorrectly attribute wage changes to privatization. These differential trends may arise for a variety of reasons. For example, it is likely more difficult to obtain a job in an SOE than in a private-sector establishment, and so when we compare a worker in an SOE to a worker in a private establishment, it may not be surprising to observe both different wage levels and different trends. Similarly, comparing a privatized worker to a worker in a never-privatized SOE may be confounded if there is selection into which establishments get privatized. For example, if the most productive SOEs also have the most productive workers, then privatization may be correlated with unobserved productivity which could cause privatized workers to be on a different wage trend than workers in never-privatized SOEs ${ }^{20}$

The second assumption is that there are no shocks that coincide with privatization. One consequence of this assumption is that privatization has no treatment effect on non-privatized workers. However, as discussed in Section III, the impacts of privatization could spillover to other establishments. This general equilibrium response will attenuate the direct impact of privatization toward zero and understate the impact of privatization on workers. In Section VI I directly estimate these types of spillovers and find that general equilibrium effects are important to take into consideration. Therefore, the estimates in this section may be interpreted as lower bounds.

Panel A of Figure 3 plots $\hat{\delta}_{k}$ from estimating Equation (7). As can be seen in the figure, wages between the privatized workers and the control group experience similar trends in the years before privatization, lending credibility to the parallel trends assumption. In the year after privatization there is a small but insignificant decline in wages. However, wages continue to fall in the following years, reaching a decline of roughly $30.0 \log$ points that levels off and does not recover. The gradual decline in wages may be due to a combination of wage rigidity and declining union bargaining power. In particular, Guimarães (2007) documents anecdotal evidence that following privatization in Brazil, the telecommunications unions were unable to secure mandatory raises or raises pegged to inflation, which may explain the gradual decline in wages post-privatization.

\footnotetext{
${ }^{20}$ Managers for public-sector establishments in Brazil must pass a difficult test in order to be hired.
} 
Panel A of Table 3 summarizes the event-study results. Given the dynamic nature of the treatment effects, I aggregate the impacts into a short-run effect (average $\delta^{k}$ within first four years of privatization) and a long-run effect (average $\delta^{k}$ years five through ten following privatization) ${ }^{21}$ Column 1 shows that in the short run wages fall by $5.8 \log$ points in privatized establishments relative to the matched control group, while in the long run, this loss grows to $22.3 \log$ points, with both effects being significant at the one percent level.

There are two factors contributing to the decline in wages post-privatization. First, individuals in privatized establishments may lose their jobs during privatization and find jobs at lower-paying establishments. Second, even conditional on staying in the establishment, wages may fall relative to the control workers if privatization causes a decline in wages within an establishment. To isolate the latter channel, I estimate the effect for establishment stayers. A worker is defined as a stayer in time period $t$ if the individual is still employed at the same firm she was employed at in time period $t=t^{*}-1$, where $t=t^{*}$ is the period the establishment is privatized 22 For control workers, the year of privatization is defined as the year the corresponding treated worker's establishment is privatized. Panel B of Figure 3 plots $\delta^{k}$ from estimating Equation (7) restricting the estimation to individuals who remain employed at the establishment they were working for in the year prior to privatization.

As can be seen in Panel B of Figure 3, the impact of privatization conditional on remaining in the privatized establishment is equal to about $-17.0 \log$ points ten years after privatization, about half the size of the unconditional effect. Therefore, about half the decrease in wages in privatization is due to workers being displaced and finding jobs at lower-paying establishments, while half is due to within-establishment changes in wages. This suggests that the large wage premium associated with SOEs is not due to unobserved productivity, but is true conditional on worker productivity. Panel B of Table 3 presents wage regression results for establishment stayers. In the short run, there is an insignificant drop in wages of 1.0 log points, while in the long run there is a significant drop of $11.0 \log$ points.

One important caveat to this analysis is that it is conditional on positive earnings. In Brazil, nearly 40 percent of the workforce is employed in the informal sector, therefore it would be incorrect to interpret an individual dropping out of the sample as unemployment or out of the labor force. However, if privatization increases the probability a worker is displaced, then the estimates so far would understate the total negative impact of privatization on worker welfare, given that displacement is associated with large persistent earnings losses (Jacobson, LaLonde and Sullivan, 1993).

To explore this possibility, Panel A of Figure 4 plots the probability a worker is employed in the formal sector relative to the year of privatization. The probability of remaining in the sample decreases over time for both the privatized sample and the matched control group due to workers switching to informal jobs, unemployment, and retirement. In ten years, approximately half of all workers are no longer employed in

\footnotetext{
${ }^{21}$ Following the advice of Borusyak and Jaravel (2016), the short-run and long-run effects are estimated by first estimating Equation (7) allowing for flexible dynamics in treatment effects and then manually averaging the coefficients, weighting by the sample size at each point.

${ }^{22}$ In administrative datasets firm identifiers can change for multiple reasons. For example, tax identifiers may change after mergers and acquisitions. I recode these transitions as remaining within the firm by identifying such administrative changes using worker flows following Benedetto et al. (2007). If at least 70 percent of workers in firm A move to firm B in period $t$, then all workers in firm A that move to firm B are classified as stayers.
} 
the formal sector. However, the probability of remaining employed in the formal sector is higher for the control group. Panel B of Figure 4 plots $\delta^{k}$ from estimating Equation (7) with formal sector employment as the outcome. As can be seen in the figure, the probability of formal sector employment drops by 10 percentage points in the privatized SOEs relative to the control group two years after privatization. This effect remains relatively constant throughout the next ten years.

This gap has important consequences for the interpretation of the wage effects. If informal sector jobs pay lower on average, then the long-run wage effect of -30.0 log points in Figure 3 represents a lower bound, as it does not capture the fact that privatized workers are more likely to transition into the informal sector where they earn lower wages on average. While it is not possible to observe informal workers in the RAIS, the Brazilian National Household Survey, Pesquisa Nacional por Amostra de Domicilios (PNAD) contains information on informal work as well as information on wages and sector. Therefore, it allows one to estimate formal-informal wage gaps while controlling for a variety of observables ${ }^{23}$

To estimate the informal-formal wage gap, I estimate a regression of the following form:

$$
\ln \left(w_{i t}\right)=\beta \text { Informal }_{i t}+\gamma_{t}+\xi_{s}+\chi_{o}+\zeta_{r}+\pi X_{i t}+\varepsilon_{i t}
$$

Where Informal $_{i t}$ indicates that worker $i$ is employed in the informal sector at time $t, \gamma_{t}$ are year indicators, $\xi_{S}$ are industry fixed effects, $\chi_{o}$ are occupation fixed effects, $\zeta_{r}$ are state fixed effects, and $X_{i t}$ is a vector of covariates which includes a cubic in age, tenure within the firm in months, union status, education in years, and number of jobs held. As can be seen in Column 1 of Appendix Table A2, when pooling all industries, I find an informal-sector wage penalty equal to $-0.324 \sqrt{24}$ Restricting to just the privatized industries dramatically reduces the sample, but I still find a statistically significant wage penalty equal to -0.264 . Therefore, if privatization increases the probability a worker transitions to the informal sector, as Figure 4 finds, then this transition is associated with a large wage penalty which is not captured in the previous event-study specifications, given the estimates are conditional on positive earnings in the formal sector. Therefore, the total impact of privatization on earnings for incumbents workers is likely larger than previously estimated.

\section{Heterogeneity in Effects}

Guimarães (2007) documents anecdotal evidence that following privatization in Brazil, the telecommunications unions were unable to secure mandatory raises or raises pegged to inflation, which may explain the gradual decline in wages post-privatization. Therefore, declines in union bargaining power may play an important role in explaining the decline in wages in privatized SOEs. A number of studies find that unions compress wages within firms (Card, 1992; Farber et al., 2018), and therefore, we might expect low-skill workers to suffer the greatest losses from privatization. In this section, I split the subsample by education.

\footnotetext{
${ }^{23}$ The PNAD microdata and documentation is available at the Brazilian Statistical Agencies website:https://ww2.ibge.gov.br. I am thankful to Data Zoom, developed by the Department of Economics at PUC-Rio, for providing the codes for accessing IBGE microdata.

${ }^{24}$ Estimating an earnings function without state, occupation and industry fixed effects yields an informal sector wage penalty equal to -0.422 .
} 
Education is divided into three groups: no high-school degree, high-school degree, and college degree 25 For each education level, Equation (7) is estimated. Panel A of Appendix Figure A2 displays estimates of $\delta^{k}$ for the entire sample, while Panel B of Appendix Figure A2 restricts to establishment stayers.

As can be seen in Panel A of Appendix Figure A2, wage losses are largest for individuals without a highschool degree, reaching -50.1 log points ten years after privatization. For comparison, wages for individuals with a high-school degree fall $-22.1 \log$ points relative to the matched control group while workers with a college degree fall $-17.0 \log$ points relative to the control group. Columns 2-4 of Table 3 presents these results, aggregating to a short-run effect (average effect for first four years after privatization) and a longrun effect (average $\delta^{k}$ years five through ten following privatization). The short-term effect is negative in all cases, but substantially smaller than the long-run effect, consistent with decreases in bargaining power manifesting as an inability to secure wage increases, rather than immediate cuts in nominal wages.

Turning to Panel B of Appendix Figure A2, while the wage losses for stayers are still largest for workers without a high-school degree, the differences are much smaller in magnitude. Panel B, columns 2-4 of Table 3 present the results for stayers. In the short run, there is a significant wage loss of 4.0 log points only for workers without a high school degree. In the long run, wages of workers without a high-school degree in privatized establishments fall by $15.6 \mathrm{log}$ points relative to the matched control group. For comparison, wages for workers with a high-school degree (Column 3) and with a college degree (Column 4) fall by $10.5 \log$ points and $10.6 \log$ points, respectively. Therefore, while the effect of privatization on wages still depends on education, the impact is ameliorated when estimating effects only for establishment stayers. Therefore, the large differences in Panel A of Figure A2 are driven by low-educated workers being displaced and finding lower-paying jobs at other establishments. This suggests that low-educated workers especially benefit from being employed in an $\mathrm{SOE}^{26}$ Interestingly, post-privatization, wages fall by similar amounts for all workers conditional on staying within the establishment, suggesting the privatized establishments are unable to reverse the wage compression, possibly due to nominal wage rigidities.

Appendix Figure A3 presents results for the impact of privatization on the probability a worker is employed in the formal section by education. A can be seen in the figure, there is a 10 percentage point decrease in the probability of formal sector employment for privatized workers, and this effect is consistent across the education subsamples. This implies that while low-educated and high-educated workers are laid off at similar rates following privatization, the low-educated workers suffer particularly large losses from displacement.

\footnotetext{
${ }^{25}$ In the RAIS data, education is coded by the employers and is prone to miscoding. Education changes year to year and across employers for the same worker. To obtain a consistent education variable, I take the modal level of education for a worker across all years in the data as a worker's education level. A specification which splits by the skill-level of the occupation instead of the education-level yields similar results.

${ }^{26}$ In unreported results, I estimate AKM models separately for each education group and find the wage-premium associated with SOEs is larger for lower-educated workers, consistent with the low-educated workers gaining more from working at an SOE. Note that this violates the exogenous mobility assumption of the AKM framework, which assumes all workers earn the same premium at a given establishment. Therefore, when turning to establishment-level estimates of changes in AKM premiums, I allow for different premiums by education group.
} 


\section{E. Robustness}

Appendix Table A1 presents a number of robustness checks. Column 1 matches workers in privatized establishments to workers in the private sector only. Column 2 matches workers in privatized establishments to workers in never-privatized SOEs only. Column 3 presents results which winsorizes the bottom five percentiles of wages and the top five percentiles of wages. Column 4 matches workers two years prior to privatization rather than one year prior to privatization. Column 5 adds microregion and bins for establishment size to the list of variables which workers are matched on 27 Column 6 matches on more narrow definitions of industry and occupation.

Results are consistent across specifications. The most noticeable difference is that the decrease in wages due to privatization is larger when comparing to SOE workers only. This can be rationalized by the theoretical model if worker bargaining power is larger at SOEs. To see how, consider an extreme case in which workers extract all the surplus from the employment relationship in SOEs (i.e. $\gamma_{s o e}=1$ ), but none of the surplus at private-sector establishments (i.e. $\gamma_{p}=0$ ). In this case, wages at SOEs are set so that profits are zero. Therefore, wages do not depend on the outside option available to SOE workers. If privatized establishments lower wages by 10 percent, non-privatized SOEs will not respond, therefore an event study will estimate that privatization lowers wages by 10 percent for privatized workers.

Now consider how private establishments respond to changes in wages at privatized SOEs. If $\gamma_{p}=0$, then the wage is set to the outside option for private-sector workers. Imagine a case in which privatized SOEs lower wages by 10 percent. If workers are equally likely to be hired at SOEs and private-sector establishments, this will lower the value of the outside option (in expectation) by 5 percent. Therefore, privatization impacts both private-sector workers and privatized workers in this case. An event study comparing privatized workers to private-sector workers will estimate that privatization lowers wages by 5 percent. In this way, equilibrium responses by private-sector establishments are attenuating the direct impact of privatization on wages towards zero.

\section{F. External Validity}

An important caveat to the results presented so far is that they may not necessarily extrapolate to other countries undergoing privatization, and may be particular to the Brazilian setting. For example, in Section [II I found a substantial wage premium associated with working for an SOE in the years prior to privatization. Therefore, when establishments were privatized, there may have been substantial scope for reducing wages given wages were above the market level. If SOEs in other countries do not pay such substantial wage premiums, then it may be unlikely to observe such large declines in earnings following privatization. Additionally, in other countries, even if workers in SOEs are paid higher wages, privatization may not result in significant declines in wages and employment in the presence of high worker bargaining power. Both of these explanations could explain why Olsson and Tåg (2018) find that privatization does not significantly impact earnings in Sweden 28

\footnotetext{
${ }^{27}$ A microregion is an administrative boundary in Brazil similar to a commuting zone in the United States.

${ }^{28}$ Theoretically, SOEs could pay even less than private sector establishments. For example, in Malaysia, state workers have fewer collective bargaining rights than private-sector workers (Waghorne, 1999). In these cases, we might expect privatization to
} 


\section{The Effect of Privatization on Privatized Establishment Wages and Employment}

\section{A. Setup}

While the worker-level analysis is informative about incumbents, it is important to understand how privatization impacts establishment-level outcomes. The first part of this section considers the impact of privatization on establishment-level wages. Unlike the worker-level analysis, impacts on establishment wages will incorporate impacts on both incumbents and new entrants. The second part of this sections considers the impact of privatization on establishment-level employment. Understanding how establishment-level employment responds to privatization is crucial for predicting the impact of privatization on private-sector workers. For example, if privatized SOEs replace entrenched workers with new hires from the private-sector, then privatization may expand job opportunities to private-sector workers and improve outcomes. If privatization results in permanent drops in employment at privatized SOEs, then increased labor supply to the private-sector may drive down wages for all workers.

To identify the impact on establishment-level outcomes, I use the fact that privatization occurred gradually over a number of years (1996-2000). Due to the gradual rollout, the impact of privatization can be identified by comparing privatized establishments to SOEs that will be privatized at a later date. To estimate the effect of privatization on establishment outcomes, I use an event-study framework by estimating regression models of the following form:

$$
y_{j t}=\sum_{k=-4}^{4} \delta_{k}\left(t=t^{*}+k\right) \text { Privatized }_{j t}+\psi_{j}+\gamma_{t}+\varepsilon_{j t}
$$

where $y_{j t}$ is an outcome variable, Privatized Prt $_{j}=1$ if establishment $j$ has been privatized before time $t, \psi_{j}$ are establishment fixed effects, $\gamma_{t}$ are time fixed effects and $\varepsilon_{j t}$ is an error term. All standard errors are clustered at the establishment level. Each $\delta_{k}$ measures the change in the outcome variable $y_{j t}$ for the privatized establishment relative to establishments that will be privatized at a later (or earlier) date. In the worker-level regressions, the key source of identifying variation is the difference in outcomes between workers in SOEs that are privatized and workers in SOEs that are never privatized or private-sector establishments. In Equation (9), the identifying variation comes from the timing of privatization, given that all establishments in this sample are privatized at some point.

\section{B. Impact of Privatization on Establishment Wages}

Panel A of Figure 5 plots $\delta_{k}$ from Equation (9) with average log wage as the outcome. As can be seen in Panel A of Figure 5, wages trend similarly in the years prior to privatization and then fall by roughly $14.0 \log$ points in the years following privatization, consistent with the worker-level results which restrict to establishment stayers. Again there is a lag between privatization and decreases in wages. As discussed in Section IV] one potential explanation is that downward wage rigidities prevent establishments from adjusting wages immediately. To explore this possibility, Panel B of Figure 5 restricts the sample to entrants. Unlike

increase wages. 
incumbent workers, there is no clear reason why entrants' wages could not adjust immediately. As can be seen in Panel B of Figure 5, wages of new hires fall dramatically post-privatization, but begin to fall the year prior to privatization. Taken together, these results are consistent with unions losing bargaining power postprivatization. For incumbent workers, this implies they do not receive wage raises comparable to workers in private or never-privatized employers. For entrants, this implies wages fall relative to wages for entrants immediately.

One weakness of the establishment-level event study is that it may not adequately control for changes in the composition of the workforce around privatization. This may be of particular concern in this context, given that workers in privatized SOEs are more likely to be displaced than control workers. To control flexibly for worker quality, I estimate the following regression model at the worker level:

$$
\ln \left(w_{i t}\right)=\alpha_{i}+\psi_{J(i, t)}+\delta^{s r} \text { Privatized }_{J(i, t)} \cdot S R_{t}+\delta^{l r} \text { Privatized }_{J(i, t)} \cdot L R_{t}+x_{i t}^{\prime} \beta+\varepsilon_{i t}
$$

where $\alpha_{i}$ are worker fixed effects, $\psi_{J(i, t)}$ are establishment fixed effects, Privatized $_{J(i, t)}$ is an indicator which is equal to one if establishment $J(i, t)$ has been privatized at some point before year $t, S R_{t}$ is an indicator that is equal to one in the four years after privatization and zero otherwise, $L R_{t}$ is an indicator equal to one if it has been more than four years since privatization and zero otherwise, $x_{i t}$ includes an age cubic interacted with year effects, and $\varepsilon_{i t}$ is an idiosyncratic error term.

The coefficients of interest are $\delta^{s r}$ and $\delta^{l r}$, which captures on average how wages of workers within privatized establishments change in response to privatization, controlling for the worker and the establishment. I include both a short-run indicator of privatization as well as a long-run indicator to capture the empirical fact that wages respond slowly in response to privatization. Unlike the establishment-level event studies, this specification controls flexibly for worker quality. For example, if a privatized establishment upgrades the skill-level of the workforce, but does not alter compensation policies, then both $\delta$ s will be equal to zero, indicating that conditional on worker quality, privatization does not impact wages paid by the establishment. If workers' wages fall within privatized establishments, then we would expect both $\delta$ s to be negative. Given the evidence from the worker-level results, we expect both $\delta$ s to be negative, and that $\delta^{l r}<\delta^{s r}$, capturing the fact the effects gradually grow in magnitude.

To implement the estimation, I pool all years from 1993 to 2004 to estimate Equation (10). I also estimate the equation separately by education group, which allows establishment-specific wage premiums to vary by education group. Therefore, this allows high-educated workers to gain more from working at high-wage establishments and therefore relaxes the exogenous mobility assumption in the AKM literature along one dimension. Splitting by education also alleviates the computational burden of estimating the model. As can be seen in Table A4, privatization decreases wages in the short run by $4.5 \log$ points for the no-high-school degree sample, by $6.5 \mathrm{log}$ points for the high-school sample, and $7.6 \log$ points for the college degree sample. Moving to the long-run effects, the effect of privatization on wage premiums is consistently larger in magnitude than the short-run effects, which is consistent with the worker-level event studies. In the long run, wages fall by $12.1 \mathrm{log}$ points in the no high-school sample, $10.1 \mathrm{log}$ points in the high-school sample, and 9.8 log points in the college sample. All effects are significant at the 1 percent level. Therefore, even conditional on worker quality, wages fall substantially in privatized establishments. 


\section{Impact of Privatization on Establishment Employment}

Next, I estimate the impact of privatization on log establishment employment. Panel C of Figure 5 plots $\delta_{k}$ from Equation (9) with log employment as the outcome, where employment is measured as the number of workers employed in the establishment that work at least 35 hours a week. As can be seen in Panel C of Figure 5, log employment gradually falls in privatized establishments, dropping roughly 60 log points in the four years after privatization. Converting this into a proportional effects yields a 45 percent decline in employment following privatization. However, as can be seen in the figure, while there is a stark trend break after privatization, log employment is falling in the year prior to privatization. Therefore, the 45 percent decline may overstate the direct impact of privatization. To correct for this, I linearly extrapolate the pretrend using the estimates in the years prior to privatization (i.e. years -4 through -1 relative to privatization). If log employment had remained on this pre-trend, it would have fallen by 17 log points. Therefore, my preferred estimate of the impact of privatization on log employment is equal to $-60-(-17)=-42$. Converting this to a proportional effect implies that privatization decreased employment by 34 percent. Together with the worker-level analysis, this shows that privatized establishments shed incumbent workers and do not replace these workers through increased hiring.

This result has important implications for other workers employed in the same labor market as workers in privatized SOEs. Through the lens of the bargaining model illustrated in Section [II], this fall in employment has two implications. First, this will cause an influx of workers into the private-sector labor market. This labor-supply effect will dcrease the equilibrium wage in the private sector, as there are now more workers competing over private-sector jobs. Second, falling employment at privatized SOEs may decrease the probability a private-sector worker can transition into employment at the privatized SOE. This reduces the value (in expectation) of the private-sector worker's outside option and therefore further reduces the equilibrium wage.

\section{Estimating Spillovers Due to Privatization}

\section{A. Overview}

The results in Section $\mathrm{IV}$ and Section $\mathrm{V}$ establish that privatization decreases both wages and employment in privatized SOEs. In this section, I estimate labor market spillovers due to privatization by exploiting variation across labor markets in the level of exposure to privatization. To proceed, I first provide a definition of a labor market and then define the exposure measure which will be used to identify the spillovers associated with privatization. Intuitively, the exposure measure will depend on two factors: (1) the fraction of jobs privatized within a labor market and (2) the fraction of jobs privatized in closely related labor markets, where labor markets are closely related if workers commonly transition between them.

\section{B. Labor Market Definition}

I follow Azar et al. (2017), and define the labor market by a microregion-by-occupation cell. A microregion in Brazil is a concept similar to commuting zone in the United States and has been used in Kovak 
(2013) and Menezes-Filho and Muendler (2011) to define labor markets in Brazil. In the RAIS data, approximately 75 percent of job transitions are within microregions, indicating that most transitions do occur within microregions rather than across microregions.

Occupational classifications in the RAIS follow the $C B O$ (Classificação Brasilieira de Ocupações), a five-digit classification system with a total of 2,355 individual occupations. This system is more narrowly defined than the Standard Occupational Classification (SOC) system commonly used in the United States, and in particular, in Azar et al. (2017), which contains 840 different occupations. Using the narrowest definition of the labor market may overstate the level of exposure if workers easily transition into closely related occupations. I deal with this problem in two ways. First, as will be discussed below, the exposure measure will directly take into account the possibility that workers can transition across labor markets. Second, while the main specification defines occupations at the five-digit level, I present a series of robustness checks which vary the definition of an occupation (from one-digit to four-digit).

\section{Exposure Measure}

To begin, let $P_{i t}$ be the proportion of jobs in labor market $l_{i}$ in 1995 that are privatized at time $t$. One way to define the exposure measure would be to use $P_{i t}$ directly as the measure. However, this would ignore the fact that many transitions in the data are between labor markets, rather than within, and could understate (or overstate) a given labor market's exposure to privatization. For example, suppose all electrical technician jobs in a region are privatized, but electrical technicians can easily transition into technician jobs available in other engineering fields, such as civil or computer engineering. Then using $P_{i t}=100$ for electrical technicians is likely to overstate the exposure to privatization 29

Therefore, the exposure measure for a worker in labor market $l_{i}$ is based on the level of privatization $\left(P_{i t}\right)$ in labor market $l_{i}$, as well as the level of privatization $\left(P_{m t}\right)$ in other labor markets $l_{m}$, weighted by the distance between two labor markets. The distance metric $d_{i \rightarrow m}$, is defined by the fraction of individuals in labor market $l_{i}$ who transition to a job in labor market $l_{m}$ in the years prior to privatization. Formally, for labor market $l_{i}$, the exposure to privatization at time $t$ is given by:

$$
\text { Exposure }_{i t}=\sum_{t^{\prime} \leq t} \sum_{m=1}^{L} d_{i \rightarrow m} P_{m t^{\prime}}
$$

Where $P_{m t^{\prime}}$ is the proportion of jobs in labor market $m$ which are privatized in time period $t^{\prime}$. Note that if all the jobs a worker may transition to are privatized, the exposure measure for this worker's labor market will be equal to 100. If none of the jobs a worker may transition to are privatized, the exposure measure will be equal to zero. Also, note that the exposure measure is cumulative. Since I restrict analysis to events which occur between 1996-2000, the exposure measure for labor market $l_{i}$ reaches its maximum value in 2000, at which point it stays constant across the sample period.

At the five-digit occupation level, there are 94,777 unique labor markets. Overall, about 3 percent of

\footnotetext{
${ }^{29}$ For example, 43 percent of electrical technicians who switch jobs transition into a different occupation. Of those who transition into other occupations, the most common transition is to mechanical engineering technician, which occurs in 10 percent of cases.
} 
the workforce in 1995 is employed in an establishment that is eventually privatized ${ }^{30}$ The exposure level, however, is highly skewed. About 14 percent of labor markets have an exposure level equal to zero, whereas the maximum exposure level is equal to 100. Overall, the mean exposure level across labor markets is equal to 3.0 with a standard deviation equal to 5.4. Appendix Figure A4 presents the distribution of Exposure $i t$ across labor markets in Panel A, as well as the distribution of $\ln \left(\right.$ Exposure $\left._{i t}+1\right)$ in Panel B. In the next section, $\ln \left(\right.$ Exposure $\left._{i t}+1\right)$ will be used to identify the impact of exposure on market wages.

\section{The Impact of Exposure to Privatization on Market Wages}

To estimate the general equilibrium spillovers, I estimate the following regression specification:

$$
\ln \left(w_{i t}\right)=\delta \ln \left(\text { Exposure }_{i t}+1\right)+\alpha_{i}+\gamma_{t}+\epsilon_{i t}
$$

Where $\ln \left(w_{i t}\right)$ is the average log wage in labor market $i$ at time $t$, which is computed excluding all observations from privatized SOEs, Exposure $e_{i t}$ is the exposure measure for labor market $i$ in year $t, \alpha_{i}$ are labor market fixed effects, and $\gamma_{t}$ are year fixed effects. The estimation includes years prior to privatization (1992-1995), and therefore in these years Exposure $i t$ is mechanically zero for all labor markets. In order to include labor markets with zero exposure into the estimation, I add one to Exposure $i t$ before taking the logarithm so that the minimum of $\ln \left(\right.$ Exposure $\left._{i t}+1\right)$ is equal to zero. An alternative way to incorporate zeros into the analysis is to take hyperbolic sine (asinh) of the exposure measure. The asinh function closely parallels the natural logarithm function, but is well defined at zero. To show robustness to the exact transfor-

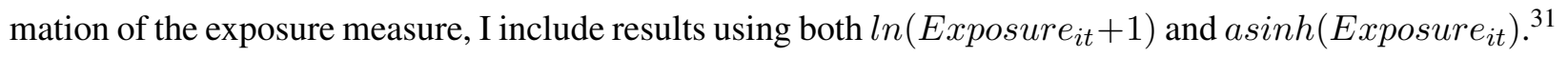
All standard errors are clustered at the labor market level.

Table 5 presents the results from estimating Equation (12). A one standard deviation in log exposure (0.53) decreases wages by $1.6 \log$ points $(0.031 \times 0.53)$, indicating exposure is associated with a significant decline in the market wage. However, there are a number of concerns when estimating Equation (12). First, while the exposure measure does allow for links across labor markets, a priori, it is unclear what the "correct" definition of a labor market should be in practice. This issue can be interpreted as inducing measurement error into the exposure measure. If the measurement error is classical, then this will attenuate the impact of exposure to privatization toward zero. However, given the large mass of labor markets with zero exposure level, the measurement error is likely non-classical, making it impossible to determine the sign of the bias. Therefore, Appendix Table A5 estimates the impact of exposure to privatization using a number of alternative market definitions. In all specifications, I continue to find a negative impact of exposure on average market wages ${ }^{32}$

\footnotetext{
${ }^{30}$ This statistic is restricted to privatization events occurring between 1996-2000 and therefore understates the total number of workers impacted by privatization in Brazil. As discussed in Section $\Pi$ a number of large federal companies were privatized before 1995, but due to data limitations, these privatization events cannot be identified in the RAIS data.

${ }^{31}$ As can be seen in Column 3 of 5 this yields similar results. For an application of the asinh function in economics see Card and DellaVigna (Forthcoming). Additionally, eliminating all labor markets with zero exposure from the analysis again yields similar results.

${ }^{32}$ While the qualitative results hold across alternative labor market definitions, the quantitative implications differ by labormarket definition. For example, when defining the labor market at the one-digit occupation level, the marginal impact of exposure on $\log$ monthly wages is equal to -0.070 compared to -0.031 at the five-digit level.
} 
A natural concern with estimating Equation $(12)$ is that the level of exposure is assumed to be random after year and labor market fixed effects are included in the specification. Suppose, however, that highskill occupations, such as electrical technicians, are more likely to be exposed to privatization, as well as more exposed to technological change which makes them more productive. In this case, the coefficient on $\ln \left(\right.$ Exposure $\left._{i t}+1\right)$ would be biased upward, given that exposure to privatization is correlated with exposure to technological change which enhances worker productivity.

To test whether exposure is correlated with worker productivity, I estimate the following event-study specification:

$$
\ln \left(w_{i t}\right)=\sum_{t=1992}^{2008} \delta_{t} \cdot\left(\ln \left(\text { Exposure }_{i, 2000}+1\right) \cdot \gamma_{t}\right)+\alpha_{i}+\gamma_{t}+\pi X_{i t}+\varepsilon_{i t}
$$

where $\ln \left(\right.$ Exposure $\left._{i, 2000}+1\right)$ is the total cumulative exposure of a labor market given the few privatization events after 2000 are excluded from the analysis. The coefficients $\hat{\delta}_{t}$ capture the effect of exposure to privatization in year $t$. If exposure to privatization is random conditional on control variables, then $\delta_{t}$ should be zero in the years prior to privatization. If $\ln \left(\right.$ Exposure $\left._{i, 2000}+1\right)$ is still correlated with other factors that impact wages even conditioning on labor market fixed effects and year effects, then $\delta_{t}$ will not be equal to zero in the years prior to privatization. For example, if electrical technicians benefited from skill-biased technological change in the years before privatization, then $\delta_{t}$ would be trending upward in the years prior to privatization.

As can be seen in Figure 6, there is no clear pre-trend in the years prior to privatization. In 1996, privatization begins, and wages gradually fall in the more exposed labor markets relative to less exposed labor markets. This supports the assumption that conditional on labor market and year fixed effects, exposure to privatization is not correlated with pre-existing trends in wages.

Appendix Table A5 presents a few additional robustness checks. First, outcomes within a microregion or within an occupation may be correlated. In Column 6 I two-way cluster at the microregion and occupation level and continue to find a statistically significant impact of exposure to privatization on wages. Similarly, one may be concerned that certain microregions are on different trends and that the exposure measure is correlated with these trends. While the event-study suggests this is not the case, another way to show robustness is to include microregion-by-year fixed effects into the estimation. In this case, the effect of exposure will be identified by differences in exposure levels between different occupations in the same microregion. Column 7 includes microregion-by-year fixed effects and continues to find a negative correlation between exposure to privatization and market wages. Column 8 excludes all workers that ever work for privatized SOEs when computing the average market wage. Privatized workers who transition into the private-sector may need to "start at the bottom". In this case, declines in wages in adjacent markets may not be due to spillovers, but direct effects on the careers of privatized workers. However, excluding workers that ever work for privatized SOEs yields nearly identical results. 


\section{E. The Aggregate Impact of Privatization on the Average Wage}

The goal of this section is to describe a simple exercise to quantify the total impact of privatization on the aggregate wage. The exercise also allows one to decompose this impact into a component due to direct impacts on privatized workers, and a component due to indirect spillovers. Conceptually, the exercise takes all workers in 1995 (the year prior to the privatization period discussed in this paper) and uses the eventstudy estimates to create the counterfactual wages which would occur if the impacts of privatization occurred immediately in 1995. I first compute the impact of privatization using only the direct impacts on privatized workers. I then compare to an exercise which incorporates the general equilibrium spillovers. First, to construct the counterfactual wage with no spillovers, $w_{i}^{n s}$, for worker $i$, I form:

$$
w_{i}^{n s}=w_{i}+\hat{\beta} \text { Privatized }_{i}
$$

where $\hat{\beta}$ is the direct impact on privatized workers and $w_{i}$ is the actual wage. Note that for any worker not in a privatized establishment, the counterfactual wage will be equal to the actual wage. In Figure 3, I found the long-run impact of privatization on wages is equal to about -0.30 . However, this estimate is downward biased if control workers are exposed to privatization, and therefore also experience wage declines following privatization. Therefore, I form $\hat{\beta}$ by taking into account the exposure of the control group to privatization:

$$
\hat{\beta}=-0.30+\hat{\delta} \cdot \mathbb{E}[\text { Exposure } \mid \text { Control }]
$$

where $\hat{\delta}$ is the estimated impact of exposure to privatization on wages. I find $\hat{\delta}=-.031$ and $\mathbb{E}[$ Exposure $\mid$ Control $]=$ 1.34 , implying $\hat{\beta}=-0.34$. Therefore, the aggregate impact of privatization using only direct impacts is equal to:

$$
\Delta w^{\text {direct }}=\mathbb{E}\left[w_{i}^{n s}\right]-\mathbb{E}\left[w_{i}\right]=-0.011
$$

Next, I form the counterfactual wages which incorporate spillovers::

$$
w_{i}^{s}=w_{i}+\hat{\beta} \text { Privatized }_{i}+\left(1-\text { Privatized }_{i}\right) \cdot \hat{\delta} \text { Exposure }_{i}
$$

The aggregate impact of privatization on wages with both direct and spillovers is then formed by:

$$
\Delta w^{\text {total }}=\mathbb{E}\left[w_{i}^{s}\right]-\mathbb{E}\left[w_{i}\right]=-0.045
$$

Therefore, the aggregate impact incorporating spillovers is about four times as large as the direct impact alone ${ }^{33}$ In this setting, incorporating spillovers is crucial for estimating the total impact of privatization on

\footnotetext{
${ }^{33}$ This number changes depending on the exact specification used for estimating spillovers. For example, the specification which restricts to manufacturing establishments finds $\hat{\delta}=-0.02$. In this case, the direct impact of privatization is still equal to -0.011 , but the aggregate impact is equal to -0.032 . Therefore, while the magnitudes change slightly, the qualitative conclusions remain the same. Additionally, these decompositions may have different interpretations. The decomposition in the main text may incorporate impacts of product market competition which spillover to workers, while the decomposition using the manufacturing estimates abstracts from product market effects by focusing on establishments in which prices are determined on a global market.
} 
the labor market 34

\section{F. Distinguishing Between Alternative Spillover Channels}

In terms of the model presented in Section III, these negative spillovers may arise through three different channels. First, changes in product-market competition due to privatization may impact labor demand. Second, large declines in employment at SOEs will increase the supply of workers to private-sector firms, reducing the equilibrium wage. Third, the outside option for workers may decline in response to employment and wage cuts at privatized SOEs. Unfortunately, without data on product market prices, it is difficult to predict how product market spillovers contribute to the negative spillovers. However, to understand whether product-market effects drive the negative correlation, I estimate Equation (12) restricting to the manufacturing sector in Columns 3-6 of Table 5. In manufacturing industries, the price of the output is substantially determined on a global market, and therefore, may be less prone to changes driven by privatization. In manufacturing industries, I find a one standard deviation in log exposure (0.53) decreases wages by $1.2 \log$ points $(0.022 \times 0.53)$. In comparison, a specification which includes all industries finds that a one standard deviation decreases wages by 1.6 log points. Therefore, product-market competition may potentially explain about one-third of the total effect. The remaining portion can be explained by either (1) deteriorating outside options (2) increases in labor supply.

One way to potentially disentangle the remaining mechanisms is to control directly for the size of the labor market. If increases in labor supply explain the results, then exposure should impact wages through the size of the labor market. It is important to note that when estimating the impact of exposure on market wages, I exclude workers from privatized SOEs. Therefore, a labor market will increase in size if privatized workers move to private-sector firms, as these workers were previously not included in estimating the average market wage. It is important to note that this is certainly not a perfect test. Falling employment at SOEs impacts both the outside option and labor-supply of the market and therefore does not cleanly isolate the impact of outside options only. However, even controlling for the labor market size, privatization will impact the outside option for workers through reduced wages at privatized SOEs. In Column 3 of Table 5 I add the logarithm of labor-market size to the linear regression and find the effect of exposure on wages to be unchanged. Alternative specifications, such as controlling more flexibly for size yields nearly identical results. I interpret these results as suggestive evidence that the outside option may be driving the negative spillovers, however, as discussed above, controlling for labor market size does not necessarily cleanly isolate the effects due to changing outside options.

\section{Conclusion}

Despite the importance of SOEs and the scope of privatization, few studies explore the impact on the labor market. While many studies find privatization increases the profits of firms Megginson and Netter (2001),

\footnotetext{
${ }^{34}$ The magnitude of spillovers is similar to Beaudry et al. (2012) who study a similar setting in which declines in employment in a high-wage industry (e.g. manufacturing) spill over to other industries through a reduction in the outside option available to workers in other industries. They find that spillovers through reductions in the outside option magnify the direct impact by about 3-4 times.
} 
theoretically, privatization could decrease worker welfare (Birdsall and Nellis, 2003). This paper studies the impact of privatization on workers in Brazil, which implemented one of the world's largest privatization programs the 1990s. I find that wages fall by roughly 30 log points ten years after privatization for workers in privatized SOEs relative to control workers. Decomposing this wage loss, I find that approximately half is due to workers in privatized establishments being displaced and transitioning to lower-paying establishments, while half is due to within-establishment changes in compensation policies.

Turning to establishment-level outcomes, I find that establishments significantly reduce employment. The large wage and employment reductions at privatized SOEs may have important impacts on other workers in the same labor markets. First, large reductions in employment at SOEs will increase the supply of labor to the private sector, resulting in lower equilibrium wages. Second, wage and employment cuts at privatized SOEs will reduce the expected value of the outside option for workers, again resulting in wage declines. To identify spillovers, I construct a measure of exposure to privatization at the occupation-by-region level which traces how the impacts of privatization propagate through other firms in labor markets connected to privatized SOEs by labor mobility. I find that wages decline in labor markets that are more exposed to privatization relative to labor markets that are less exposed to privatization. A simple back-of-the-envelope calculation suggests that privatization decreased the aggregate wage in Brazil by about $4.5 \log$ points, with about one-quarter of this effect attributable to the direct impact on privatized workers and three-quarters attributable to spillovers.

These results imply that privatization can have large, negative impacts on workers. However, without firm-level data on output and prices, the total welfare impact of privatization is unknown. While a long literature finds firm profitability increases following privatization, the source of the gain remains unclear in many contexts. Increases in efficiency will contribute to economic growth and therefore privatization may be welfare enhancing even if workers exposed to privatization are negatively impacted. On the other hand, if privatization increases profits only through reduced wages and employment, then the perceived benefits of privatization may work through decreased worker welfare and not increased output and lower prices. 


\section{References}

Abowd, John A and Thomas Lemieux, "The effects of product market competition on collective bargaining agreements: The case of foreign competition in Canada," The Quarterly Journal of Economics, 1993, 108 (4), 983-1014.

Abowd, John M, Francis Kramarz, and David N Margolis, "High wage workers and high wage firms," Econometrica, 1999, 67 (2), 251-333.

Alvarez, Jorge, Felipe Benguria, Niklas Engbom, and Christian Moser, "Firms and the decline in earnings inequality in Brazil,” American Economic Journal: Macroeconomics, 2018, 10 (1), 149-89.

Anuatti-Neto, Francisco, Milton Barossi-Filho, A Gledson De Carvalho, and Roberto Bras Matos Macedo, "Costs and benefits of privatization: Evidence from Brazil," 2003.

Azar, José, Ioana Marinescu, and Marshall I Steinbaum, "Labor market concentration,” No. w24147 National Bureau of Economic Research, 2017.

Barth, Erling, Alex Bryson, James C Davis, and Richard Freeman, "It's where you work: Increases in the dispersion of earnings across establishments and individuals in the United States," Journal of Labor Economics, 2016, 34 (S2), S67-S97.

Beaudry, Paul, David A Green, and Benjamin Sand, "Does industrial composition matter for wages? A test of search and bargaining theory," Econometrica, 2012, 80 (3), 1063-1104.

Benedetto, Gary, John Haltiwanger, Julia Lane, and Kevin McKinney, "Using worker flows to measure firm dynamics," Journal of Business \& Economic Statistics, 2007, 25 (3), 299-313.

Birdsall, Nancy and John Nellis, "Winners and losers: assessing the distributional impact of privatization," World development, 2003, 31 (10), 1617-1633.

Bloom, Nicholas, Mark Schankerman, and John Van Reenen, "Identifying technology spillovers and product market rivalry," Econometrica, 2013, 81 (4), 1347-1393.

Borusyak, Kirill and Xavier Jaravel, “Revisiting event study designs,” 2016.

Boycko, Maxim, Andrei Shleifer, and Robert Vishny, Privatizing russia, MIT press, 1997.

Brown, James N and Orley Ashenfelter, "Testing the efficiency of employment contracts," Journal of political economy, 1986, 94 (3, Part 2), S40-S87.

Burdett, Kenneth and Dale T Mortensen, "Wage differentials, employer size, and unemployment," International Economic Review, 1998, pp. 257-273.

Card, David, "The effect of unions on the distribution of wages: redistribution or relabelling?," No w4195. National Bureau of Economic Research, 1992. 
_, Ana Rute Cardoso, Jorg Heining, and Patrick Kline, "Firms and labor market inequality: Evidence and some theory," Journal of Labor Economics, 2018, 36 (S1), S13-S70.

- and Stefano DellaVigna, "What do editors maximize? Evidence from four leading economics journals," Review of Economics and Statistics, Forthcoming.

_ , Jorg Heining, and Patrick Kline, "Workplace heterogeneity and the rise of West German wage inequality," The Quarterly Journal of Economics, 2013, 128 (3), 967-1015.

Chong, Alberto and Florencio Lopez de Silanes, Privatization in Latin America: myths and reality, The World Bank, 2005.

Farber, Henry S, “The analysis of union behavior," Handbook of labor economics, 1986, 2, 1039-1089.

_, Daniel Herbst, Ilyana Kuziemko, and Suresh Naidu, "Unions and Inequality Over the Twentieth Century: New Evidence from Survey Data," No. w24587. National Bureau of Economic Research, 2018.

Firpo, Sergio and Gustavo Gonzaga, "Going private: public sector rents and privatization in Brazil," Anais do Encontro Brasileiro de Econometria, 2010, 32.

Goldschmidt, Deborah and Johannes F Schmieder, "The rise of domestic outsourcing and the evolution of the German wage structure," The Quarterly Journal of Economics, 2017, 132 (3), 1165-1217.

Guimarães, Sonia MK, "Brazil's Telecom Unions Confront the Future: Privatization, Technological Change, and Globalization," International Labor and Working-Class History, 2007, 72 (1), 42-62.

Hornstein, Andreas, Per Krusell, and Giovanni L Violante, "Frictional wage dispersion in search models: A quantitative assessment," American Economic Review, 2011, 101 (7), 2873-98.

Iacus, Stefano M, Gary King, and Giuseppe Porro, "Causal inference without balance checking: Coarsened exact matching," Political analysis, 2012, 20 (1), 1-24.

Jacobson, Louis S, Robert J LaLonde, and Daniel G Sullivan, "Earnings losses of displaced workers," The American Economic Review, 1993, pp. 685-709.

Jaravel, Xavier, Neviana Petkova, and Alex Bell, "Team-specific capital and innovation," American Economic Review, 2018, 108 (4-5), 1034-73.

Khwaja, Asim Ijaz and Atif Mian, "Do lenders favor politically connected firms? Rent provision in an emerging financial market," The Quarterly Journal of Economics, 2005, 120 (4), 1371-1411.

Kline, Patrick, Neviana Petkova, Heidi Williams, and Owen Zidar, "Who profits from patents? rentsharing at innovative firms," No. w25245. National Bureau of Economic Research, 2018.

Kovak, Brian K, "Regional effects of trade reform: What is the correct measure of liberalization?," American Economic Review, 2013, 103 (5), 1960-76. 
Lane, Nathan, "Manufacturing Revolutions: Industrial Policy and Networks in South Korea," Stockholm: Institute for International Economic Studies., 2017.

Megginson, William L, "Privatization, state capitalism, and state ownership of business in the 21st century," Foundations and Trends $\mathrm{R}$ in Finance, 2017, 11 (1-2), 1-153.

- and Jeffry M Netter, "From state to market: A survey of empirical studies on privatization," Journal of economic literature, 2001, 39 (2), 321-389.

Menezes-Filho, Naércio Aquino and Marc-Andreas Muendler, "Labor reallocation in response to trade reform,” No. w17372. National Bureau of Economic Research, 2011.

Moretti, Enrico, "Local labor markets," in "Handbook of labor economics," Vol. 4, Elsevier, 2011, pp. 1237-1313.

Muendler, Marc-Andreas, James E Rauch, and Oana Tocoian, "Employee spinoffs and other entrants: Stylized facts from Brazil," International Journal of Industrial Organization, 2012, 30 (5), 447-458.

Olsson, Martin and Joacim Tåg, "What is the Cost of Privatization for Workers?," 2018.

Pissarides, Christopher A, Equilibrium unemployment theory, MIT press, 2000.

Porta, Rafael La and Florencio Lopez de Silanes, “The benefits of privatization: Evidence from Mexico," The Quarterly Journal of Economics, 1999, 114 (4), 1193-1242.

Postel-Vinay, Fabien and Jean-Marc Robin, "Equilibrium wage dispersion with worker and employer heterogeneity," Econometrica, 2002, 70 (6), 2295-2350.

Rosenthal, Stuart S and William C Strange, "Evidence on the nature and sources of agglomeration economies," in "Handbook of regional and urban economics," Vol. 4, Elsevier, 2004, pp. 2119-2171.

Smith, Matthew, Danny Yagan, Owen Zidar, and Eric Zwick, "Capitalists in the Twenty-first Century," UC Berkeley and University of Chicago Working Paper, 2017.

Song, Jae, David J Price, Fatih Guvenen, Nicholas Bloom, and Till Von Wachter, "Firming Up Inequality," The Quarterly Journal of Economics, Forthcoming.

Subramanian, Krishnamurthy and William Megginson, "Employment protection laws and privatization," The Journal of Law and Economics, 2018, 61 (1), 97-123.

Waghorne, Mike, "Public sector trade unions in the face of privatisation," Development in Practice, 1999, $9(5), 557-568$. 
Figure 1: Number of Workers Employed in Privatized Establishments by Year

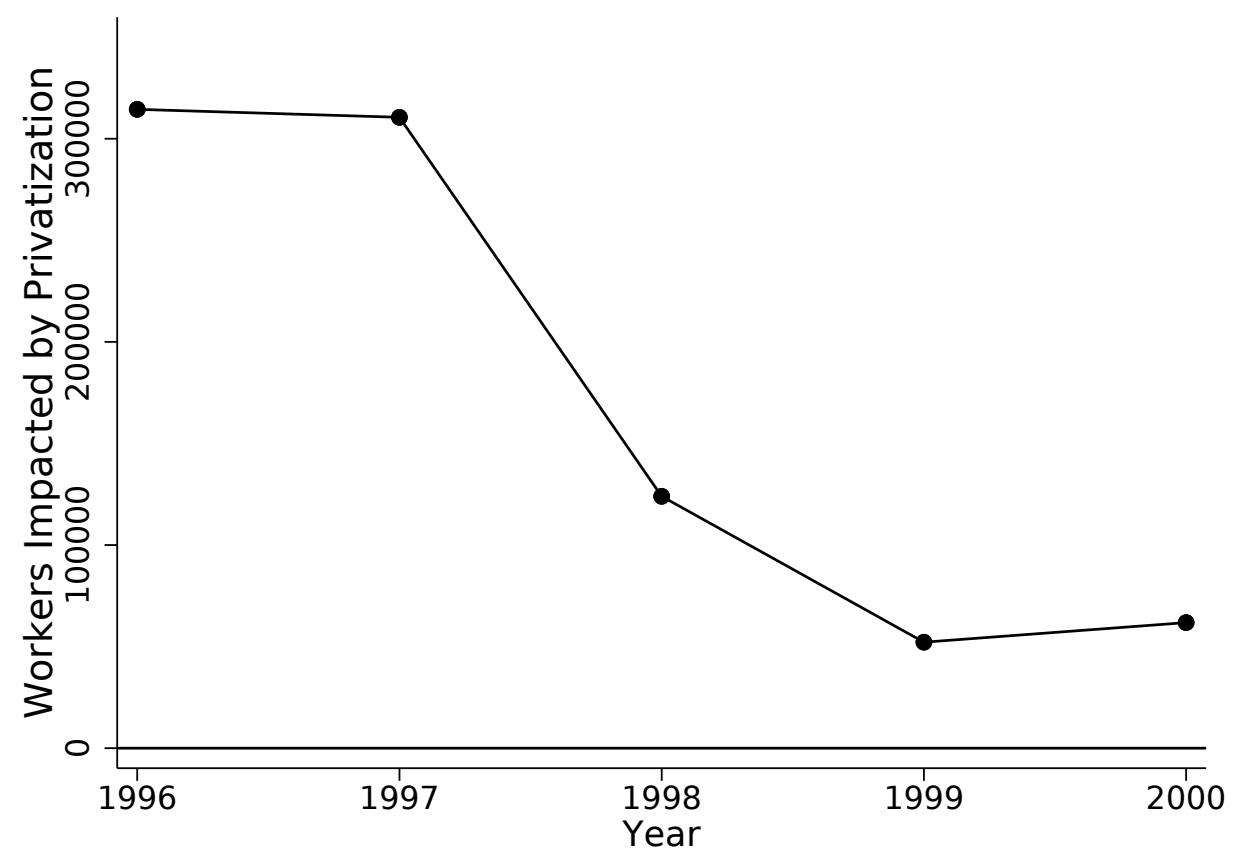

Note: This figure reports the number of workers employed in establishments that undergo privatization in a given year. Establishments are identified as privatized if the legal nature of the establishment changes from SOE to private and does not change back in a later year. 
Figure 2: Average Log Monthly Wages of Privatized Workers and Matched Control Group

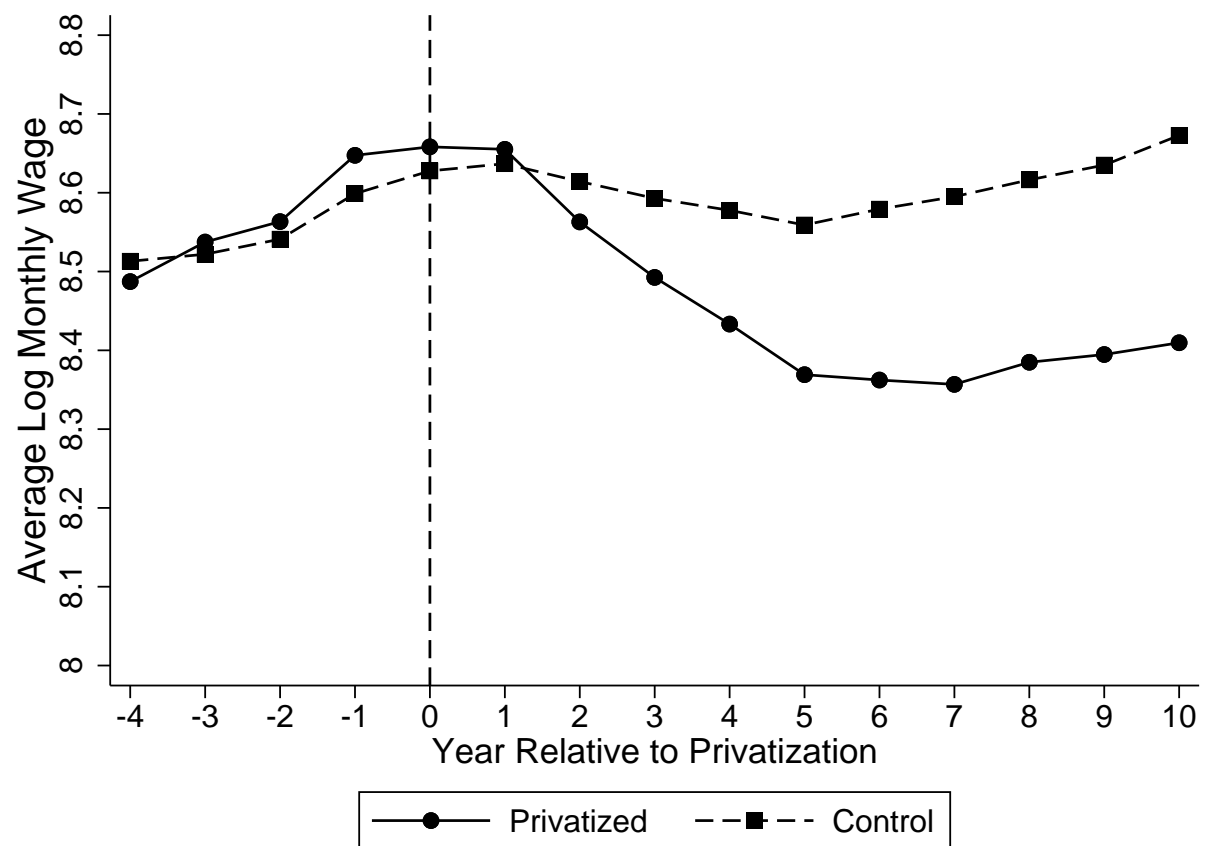

Note: This figure displays the average log monthly wage for workers in privatized establishments compared to a control group. The control group is constructed by matching workers in privatized SOEs to workers employed in either private-sector establishments or never-privatized SOEs. The matching variables include two-digit occupation, two-digit industry and bins for age (where age bins are five-year increments). The panel is not balanced as individuals may transition into unemployment, retirement or the informal sector. The informal sector makes up roughly 40 percent of all employment in Brazil. 
Figure 3: Event-Study Estimates of the Effect of Privatization on Log Monthly Wages

$$
y_{i t}=\sum_{k=-4}^{10} \delta_{k}\left(t=t^{*}+k\right) \text { Privatized }_{i}+\alpha_{i}+\gamma_{t}+x_{i t}^{\prime} \beta+\varepsilon_{i t}
$$

Panel A: All Workers

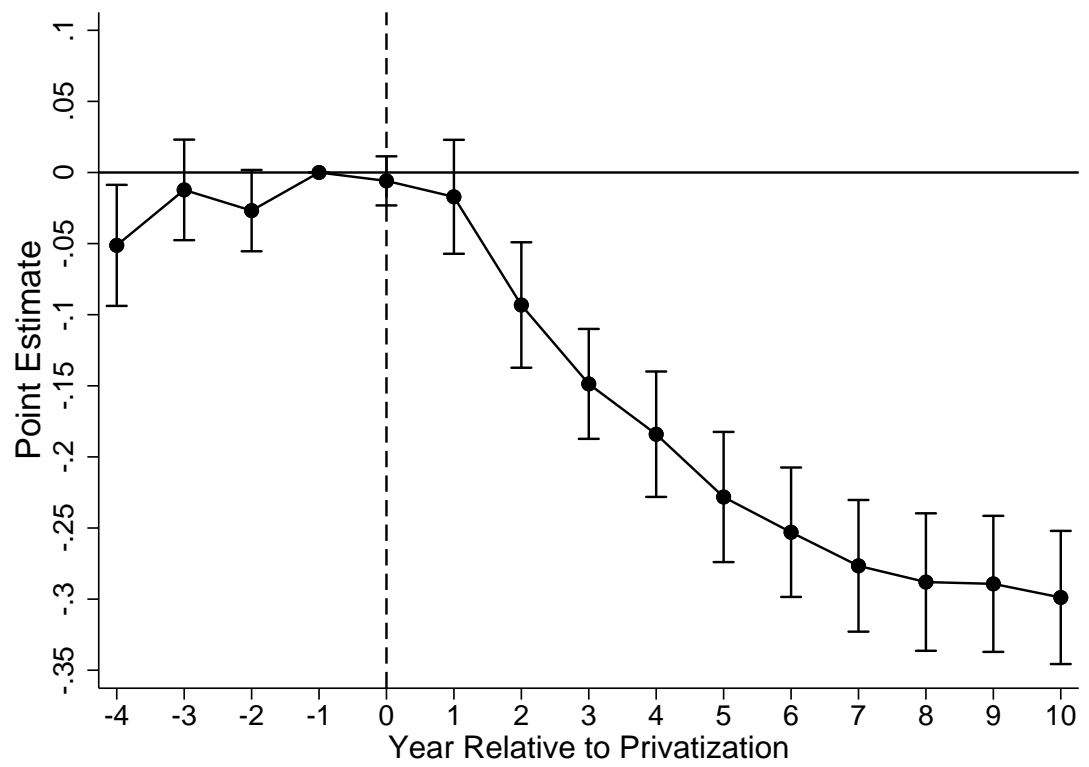

Panel B: Establishment Stayers

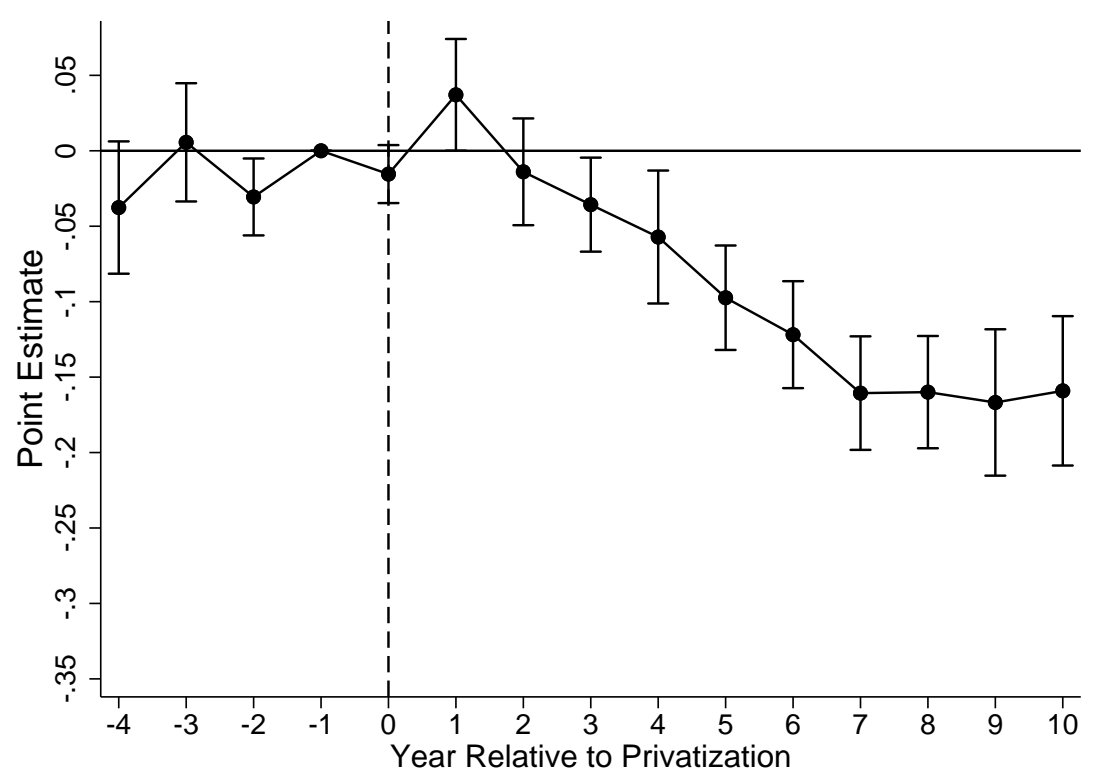

Note: This figure shows event-study estimates of the effect of privatization on log monthly wages. The omitted category is the year prior to the privatization event. The regressions control for individual fixed effects, year fixed effects, and a cubic in age. The control group is constructed by matching workers in privatized SOEs to workers employed in either private-sector establishments or never-privatized SOEs. The matching variables include two-digit occupation, two-digit industry and bins for age (where age bins are five-year increments). Standard errors are two-way clustered at the individual and establishment level. Panel A includes all workers while Panel B restricts to establishment stayers. Stayers are defined as workers in time $t$ who are employed in the same establishment as they were prior to privatization (i.e. year $t^{*}-1$ ). 
Figure 4: The Effect of Privatization on Formal Sector Employment

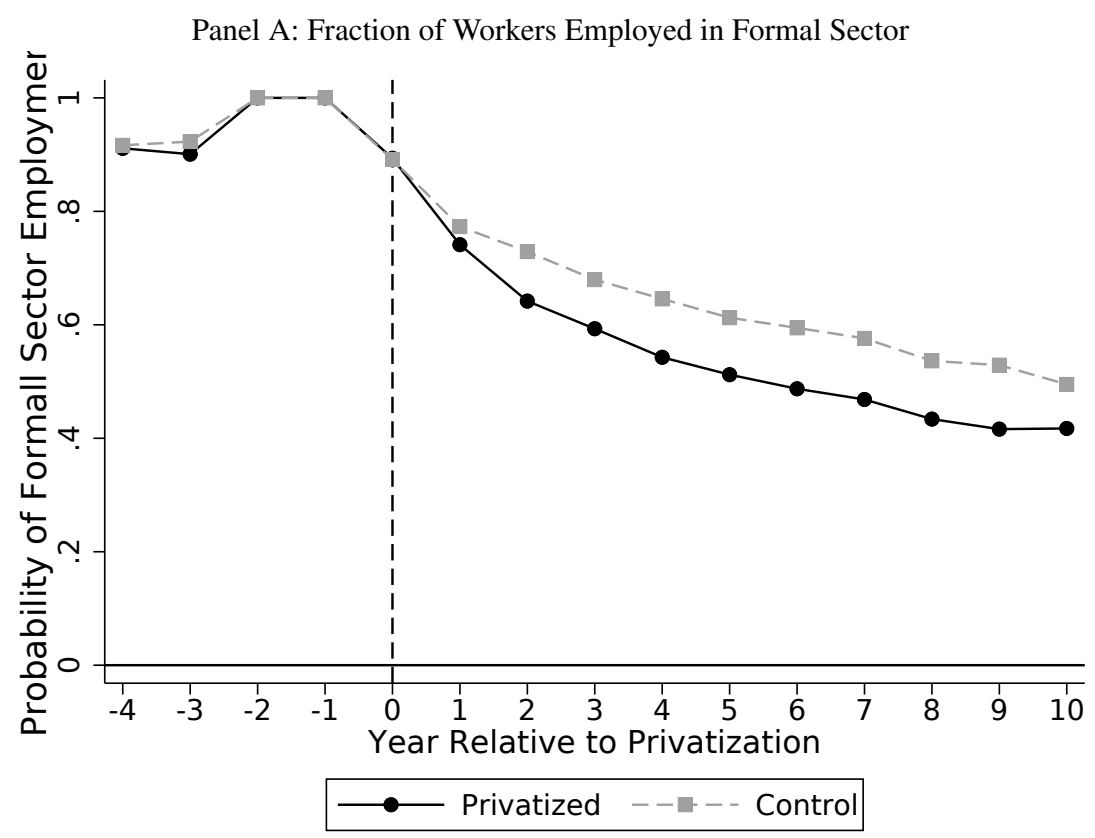

Panel B: Event Study Plot of the Impact of Privatization on Probability of Formal Sector Employment

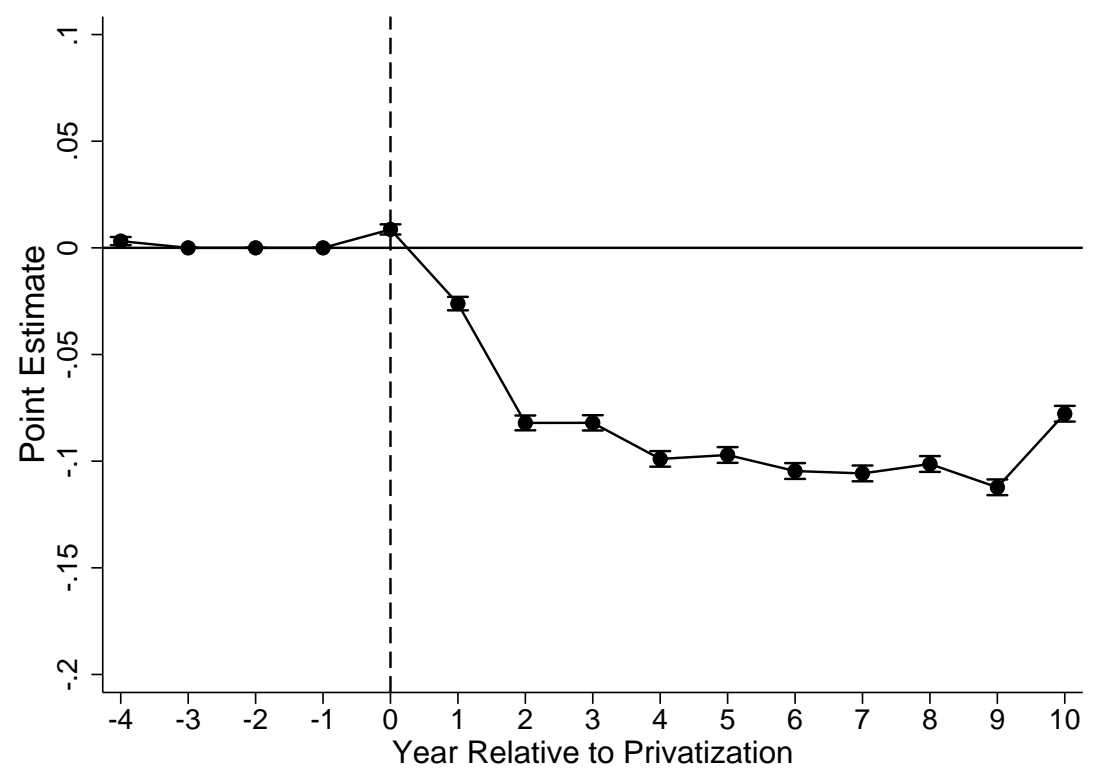

Note: This figure displays the fraction of the sample that is employed in the formal sector in each year relative to the privatization event in Panel A and event-study estimates of the effect of privatization on the probability of formal sector employment in Panel B. The omitted category is three years prior to the privatization event, given workers must be in the formal sector from years $t^{*}-2$ to $t^{*}-1$ to be in the analysis sample. The regressions control for worker fixed effects, year fixed effects and a cubic in age. The control group is constructed by matching workers in privatized SOEs to workers employed in either private-sector establishments or neverprivatized SOEs. The matching variables include two-digit occupation, two-digit industry and bins for age (where age bins are five-year increments). Standard errors in Panel B are clustered at the individual level. 
Figure 5: Event-Study Estimates of the Effect of Privatization on Establishment-Level Outcomes

$$
y_{j t}=\sum_{k=-4}^{4} \delta_{k}\left(t=t^{*}+k\right) \text { Privatized }{ }_{j t}+\psi_{j}+\gamma_{t}+\varepsilon_{j t}
$$

Panel A: Effect on Average Log Wage of All Workers

Panel B: Effect on Average Log Wage of Entrants
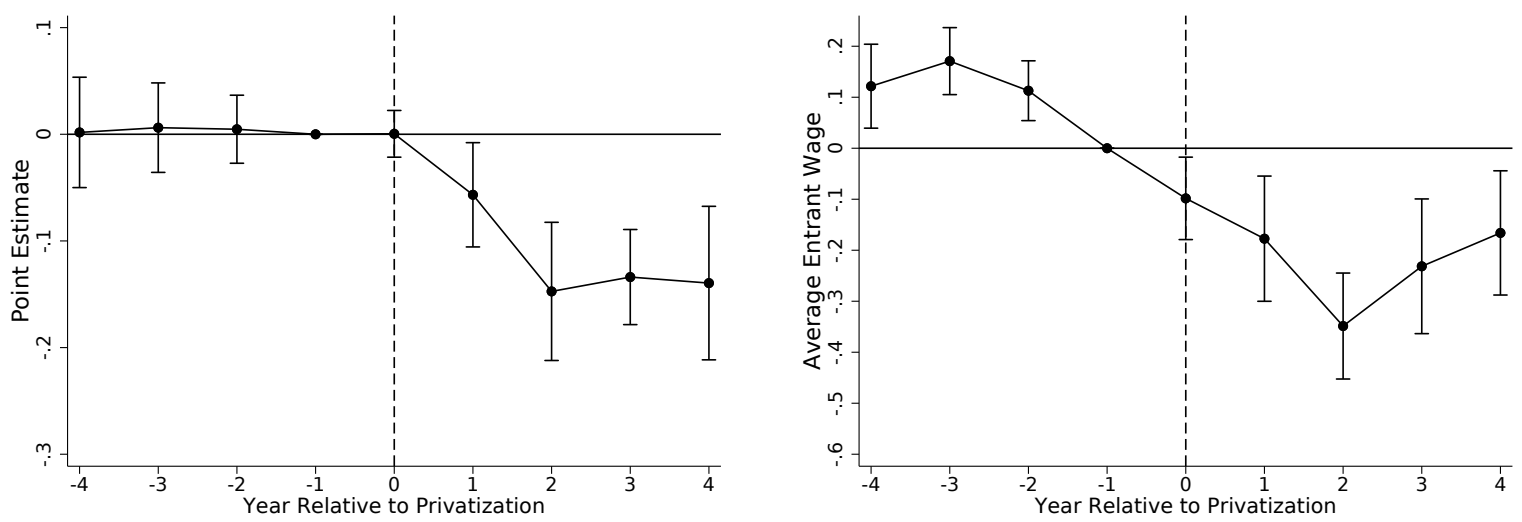

Panel C: Effect on Log Employment

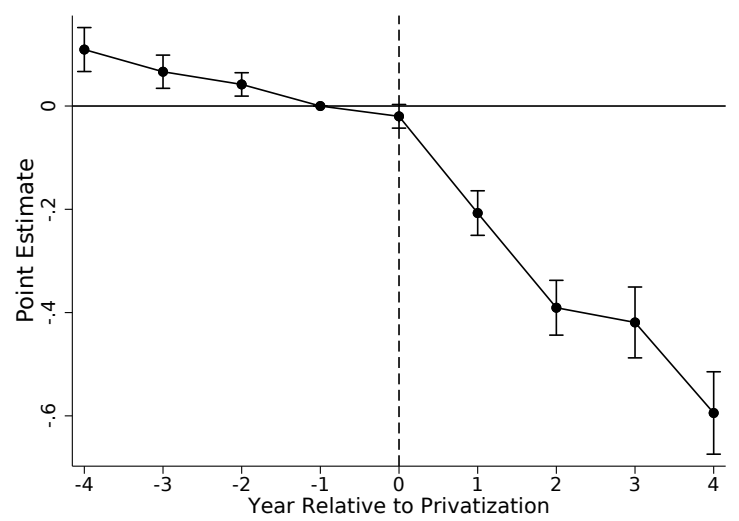

Note: This figure shows event-study estimates of the effect of privatization of establishment-level log monthly wages in Panel A, entrants' log monthly wages in Panel B and log total employment in Panel C. The omitted category is the year prior to the privatization event. The regressions control for establishment fixed effects and year fixed effects. The sample is restricted to all establishments that are privatized at some point during the sample period (1996-2000). Standard errors are clustered at the establishment level. See Appendix Table A3 for the corresponding table. 
Figure 6: Effect of Exposure to Privatization on Average Log Monthly Market Wages

$$
\ln \left(w_{i t}\right)=\sum_{t=1992}^{2008} \delta_{t} \cdot\left(\ln \left(\text { Exposure }_{i, 2000}+1\right) \cdot \gamma_{t}\right)+\alpha_{i}+\gamma_{t}+\pi X_{i t}+\varepsilon_{i t}
$$

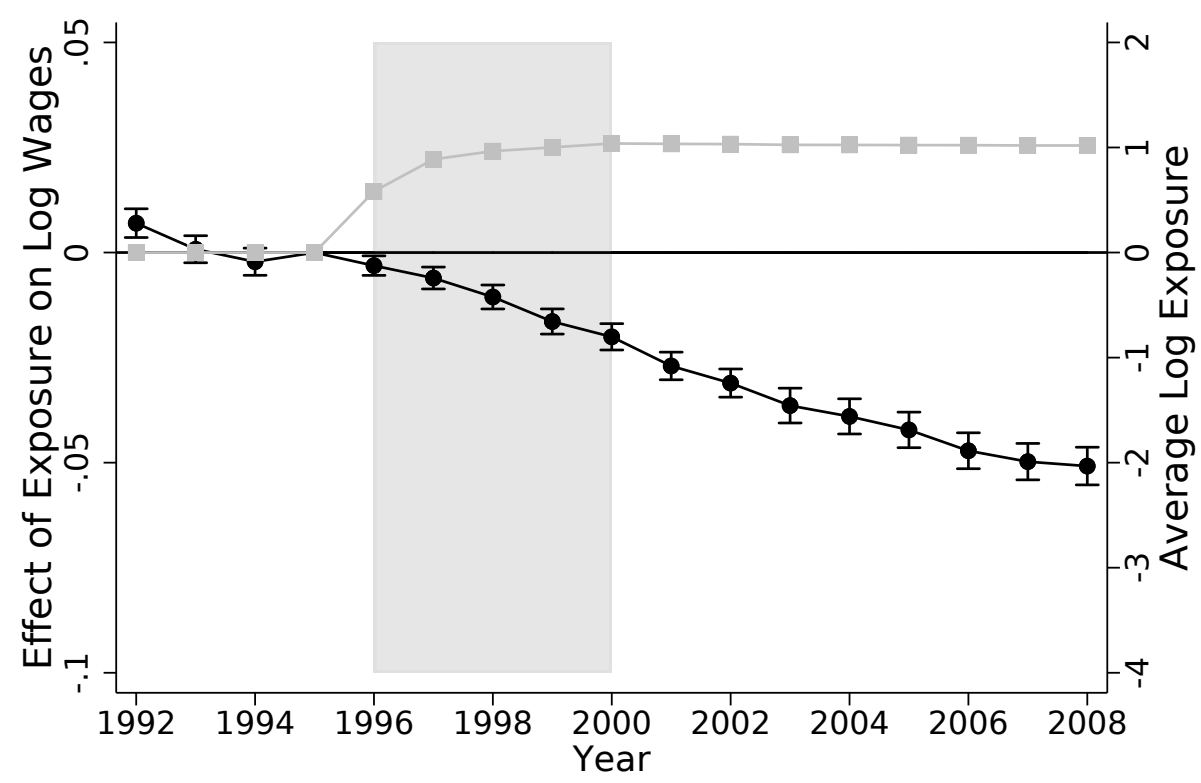

$\longrightarrow$ Exposure Effect —- Average Log Exposure

Note: This figure shows event-study estimates of the effect of exposure to privatization on log monthly market wages. The labor market is defined as an occupation-by-microregion cell, where occupations are defined at the five-digit level. The regressions control for labor market fixed effects and year fixed effects. I exclude all privatized establishments when constructing the average market wage. The gray shaded area indicates the period of privatization. Standard errors are clustered at the labor market level. 
Table 1: Wage Premium in Privatized Establishments Before Privatization

\begin{tabular}{cccccc}
\hline & All Workers & & Banking & Telecomm. & Electricity \\
\cline { 2 - 4 } \cline { 4 - 6 } AKM Wage Premium & $(1)$ & & $(2)$ & $(3)$ & $(4)$ \\
\cline { 2 - 5 } & 0.231 & & 0.141 & 0.492 & 0.174 \\
& $(0.001)$ & & $(0.003)$ & $(0.002)$ & $(0.002)$ \\
& {$[8.339]$} & & {$[8.605]$} & {$[8.019]$} & {$[8.617]$} \\
\hline
\end{tabular}

Note: The wage premium is estimated in two steps using data from 1992-1995, the years prior to any privatization event studied in this paper. In the first step, I estimate an AKM model with worker and establishment fixed effects and collect the estimated establishment fixed effects. In the second step, I restrict to SOEs that will be privatized eventually and private-sector establishments in the banking, telecommunications, and electricity sectors. I then regress the establishment fixed effects on an indicator for privatized SOE and sector fixed effects. The coefficient on the indicator for privatized SOE captures the premium associated with working for a privatized SOE in the years prior to privatization. This regression is weighted by the number of workers in a given establishment. Heteroskedastic-robust standard errors are presented. 
Table 2: Characteristics of Privatized and Non-Privatized Workers

\begin{tabular}{lccc}
\hline & Privatized & & Control \\
Panel A: Demographics & $(1)$ & & $(2)$ \\
Age & 39.17 & & 39.11 \\
High School Graduate & 0.48 & & 0.44 \\
College Graduate & 0.19 & & 0.25 \\
Male & 0.71 & & 0.73 \\
& & \\
Panel B: Job Characteristics & & \\
Log Monthly Wage & 8.64 & & 8.58 \\
& & \\
Panel C: Firm Characteristics & & \\
Median Establishment Size & 765 & \\
Financial Sector & 0.27 & \\
Telecommunications & 0.25 & & 0.27 \\
Electricity & 0.44 & & 0.25 \\
Mining Metals & 0.03 & & 0.44 \\
\hline Unique Establishments & 3,196 & & 14,661 \\
Unique Workers & 142,854 & 142,854 \\
\hline
\end{tabular}

Note: This table displays the average characteristics for privatized workers and the matched control group. Privatized workers are in the sample if they worked at the privatized firm for at least two years prior to privatization and a matched worker is found among all potential control workers. The control group is constructed by matching workers in privatized SOEs to workers employed in either private-sector establishments or never-privatized SOEs. The matching variables include two-digit occupation, two-digit industry and bins for age (where age bins are five-year increments). 
Table 3: The Effect of Privatization on Log Monthly Wages

\begin{tabular}{|c|c|c|c|c|}
\hline & $\begin{array}{c}\begin{array}{c}\text { All } \\
\text { Workers }\end{array} \\
(1)\end{array}$ & $\begin{array}{c}\text { No HS } \\
\text { Degree }\end{array}$ & $\begin{array}{c}\text { HS } \\
\text { Degree }\end{array}$ & $\begin{array}{c}\text { College } \\
\text { Degree }\end{array}$ \\
\hline \multicolumn{5}{|c|}{ Panel A: Effect of privatization on all workers } \\
\hline Post Short-run & $\begin{array}{r}-0.058 \\
(0.015)\end{array}$ & $\begin{array}{c}-0.111 \\
(0.019)\end{array}$ & $\begin{array}{r}-0.037 \\
(0.013)\end{array}$ & $\begin{array}{c}-0.039 \\
(0.015)\end{array}$ \\
\hline Post Long-run & $\begin{array}{r}-0.223 \\
(0.021)\end{array}$ & $\begin{array}{c}-0.366 \\
(0.028)\end{array}$ & $\begin{array}{r}-0.191 \\
(0.019)\end{array}$ & $\begin{array}{r}-0.152 \\
(0.022)\end{array}$ \\
\hline $\begin{array}{l}\text { Avg. Outcome at } t=-1 \\
\text { Observations }\end{array}$ & $\begin{array}{c}8.612 \\
3,867,427\end{array}$ & $\begin{array}{c}8.386 \\
933,239\end{array}$ & $\begin{array}{c}8.542 \\
1,864,219\end{array}$ & $\begin{array}{c}8.999 \\
1,069,969\end{array}$ \\
\hline \multicolumn{5}{|c|}{ Panel B: Effect of privatization on stayers } \\
\hline Post Short-run & $\begin{array}{r}-0.010 \\
(0.012)\end{array}$ & $\begin{array}{c}-0.040 \\
(0.020)\end{array}$ & $\begin{array}{r}-0.007 \\
(0.012)\end{array}$ & $\begin{array}{r}-0.015 \\
(0.012)\end{array}$ \\
\hline Post Long-run & $\begin{array}{r}-0.110 \\
(0.017)\end{array}$ & $\begin{array}{c}-0.156 \\
(0.029)\end{array}$ & $\begin{array}{r}-0.105 \\
(0.015)\end{array}$ & $\begin{array}{r}-0.106 \\
(0.019)\end{array}$ \\
\hline $\begin{array}{l}\text { Avg. Outcome at } t=-1 \\
\text { Observations }\end{array}$ & $\begin{array}{c}8.612 \\
2,524,325\end{array}$ & $\begin{array}{c}8.386 \\
661,353\end{array}$ & $\begin{array}{c}8.542 \\
1,201,209 \\
\end{array}$ & $\begin{array}{c}8.999 \\
661,763\end{array}$ \\
\hline Worker FE & Yes & Yes & Yes & Yes \\
\hline Time FE & Yes & Yes & Yes & Yes \\
\hline Demographics & Yes & Yes & Yes & Yes \\
\hline
\end{tabular}

Note: This table presents difference-in-differences estimates of the effect of privatization on log monthly wages. Column 1 pools all workers while columns 2-4 split the sample by whether the worker has no high school degree, a high-school degree or a college degree. The short-run effect is equal to the effect of privatization in the four years following privatization. The long-run effect is equal to the effect of privatization in years five through ten following privatization. Panel A includes all workers while Panel B restricts to establishment stayers which are defined as workers in time $t$ who are in the same firm as they were prior to privatization (i.e. year $\left.t^{*}-1\right)$. The control group is constructed by matching workers in privatized SOEs to workers employed in either private-sector establishments or never-privatized SOEs. The matching variables include two-digit occupation, two-digit industry and bins for age (where age bins are five-year increments). Standard errors are two-way clustered by worker and establishment. 
Table 4: The Effect of Privatization on Formal Sector Employment

\begin{tabular}{|c|c|c|c|c|}
\hline & $\begin{array}{c}\text { All } \\
\text { Workers }\end{array}$ & $\begin{array}{l}\text { No HS } \\
\text { Degree }\end{array}$ & $\begin{array}{c}\text { HS } \\
\text { Degree }\end{array}$ & $\begin{array}{l}\text { College } \\
\text { Degree }\end{array}$ \\
\hline & (1) & (2) & (3) & (4) \\
\hline Post Short-run & $\begin{array}{r}-0.045 \\
(0.001)\end{array}$ & $\begin{array}{r}-0.049 \\
(0.003)\end{array}$ & $\begin{array}{r}-0.034 \\
(0.002)\end{array}$ & $\begin{array}{r}-0.045 \\
(0.002)\end{array}$ \\
\hline Post Long-run & $\begin{array}{r}-0.098 \\
(0.002)\end{array}$ & $\begin{array}{r}-0.098 \\
(0.003)\end{array}$ & $\begin{array}{r}-0.089 \\
(0.002)\end{array}$ & $\begin{array}{r}-0.086 \\
(0.003)\end{array}$ \\
\hline Avg. Outcome & 0.677 & 0.564 & 0.710 & 0.739 \\
\hline Observations & $4,148,940$ & $1,150,110$ & $1,924,875$ & $1,073,955$ \\
\hline Worker FE & Yes & Yes & Yes & Yes \\
\hline Time FE & Yes & Yes & Yes & Yes \\
\hline Demographics & Yes & Yes & Yes & Yes \\
\hline
\end{tabular}

Note: This table presents difference-in-differences estimates of the effect of privatization on the probability a worker is employed in the formal sector. Column 1 pools all workers while columns 2-4 split the sample by whether the worker has no high-school degree, a high school degree or a college degree. The short-run effect is equal to the effect of privatization in the four years following privatization. The long-run effect is equal to the effect of privatization in years five through ten following privatization. The control group is constructed by matching workers in privatized SOEs to workers employed in either private-sector establishments or neverprivatized SOEs. The matching variables include two-digit occupation, two-digit industry and bins for age (where age bins are five-year increments). Standard errors are clustered at the worker level. 
Table 5: The Effect of Exposure to Privatization on Average Log Monthly Market Wages

\begin{tabular}{|c|c|c|c|c|c|c|}
\hline \multirow[b]{3}{*}{$\ln ($ Exposure +1$)$} & \multicolumn{3}{|c|}{ All Industries } & \multicolumn{3}{|c|}{ Tradables Only (Manufacturing) } \\
\hline & (1) & (2) & (3) & (4) & (5) & (6) \\
\hline & $\begin{array}{c}-0.031 \\
(0.001)\end{array}$ & & $\begin{array}{c}-0.031 \\
(0.001)\end{array}$ & $\begin{array}{c}-0.022 \\
(0.002)\end{array}$ & & -0.022 \\
\hline asinh(Exposure) & & $\begin{array}{c}-0.025 \\
(0.001)\end{array}$ & & & $\begin{array}{c}-0.018 \\
(0.001)\end{array}$ & \\
\hline $\ln ($ Labor Market Size $)$ & & & $\begin{array}{c}0.001 \\
(0.001)\end{array}$ & & & $\begin{array}{c}0.006 \\
(0.001)\end{array}$ \\
\hline Observations & $1,410,906$ & $1,410,906$ & $1,410,906$ & 724,837 & 724,837 & 724,837 \\
\hline R-squared & 0.891 & 0.891 & 0.891 & 0.914 & 0.915 & 0.915 \\
\hline Labor Market FE & Yes & Yes & Yes & Yes & Yes & Yes \\
\hline Year FE & Yes & Yes & Yes & Yes & Yes & Yes \\
\hline
\end{tabular}

Note: This table presents OLS estimates of the effect of exposure to privatization on log average market wage in all sectors in Columns 1-3 and in manufacturing industries only in Columns 4-6. The labor market is defined as an occupation-by-microregion cell. To construct the average market wage, all observations from privatized establishments are excluded, and therefore, changes in the market wage do not reflect the direct impacts of privatization. Exposure to privatization depends on (1) fraction of jobs privatized within the labor market and (2) fraction of jobs privatized in closely related labor market. See SectionVIfor more details on the construction of the exposure measure. Asinh is the inverse hyperbolic sine function which closely approximates the natural logarithm, but is well-defined at zero. Standard errors are are clustered at the labor market level. 


\section{Online Appendix A: Additional Results}

Appendix Figure A1: Log Monthly Wages of Privatized Workers and Matched Control Group

Panel A: Control Group: Private-Sector Workers

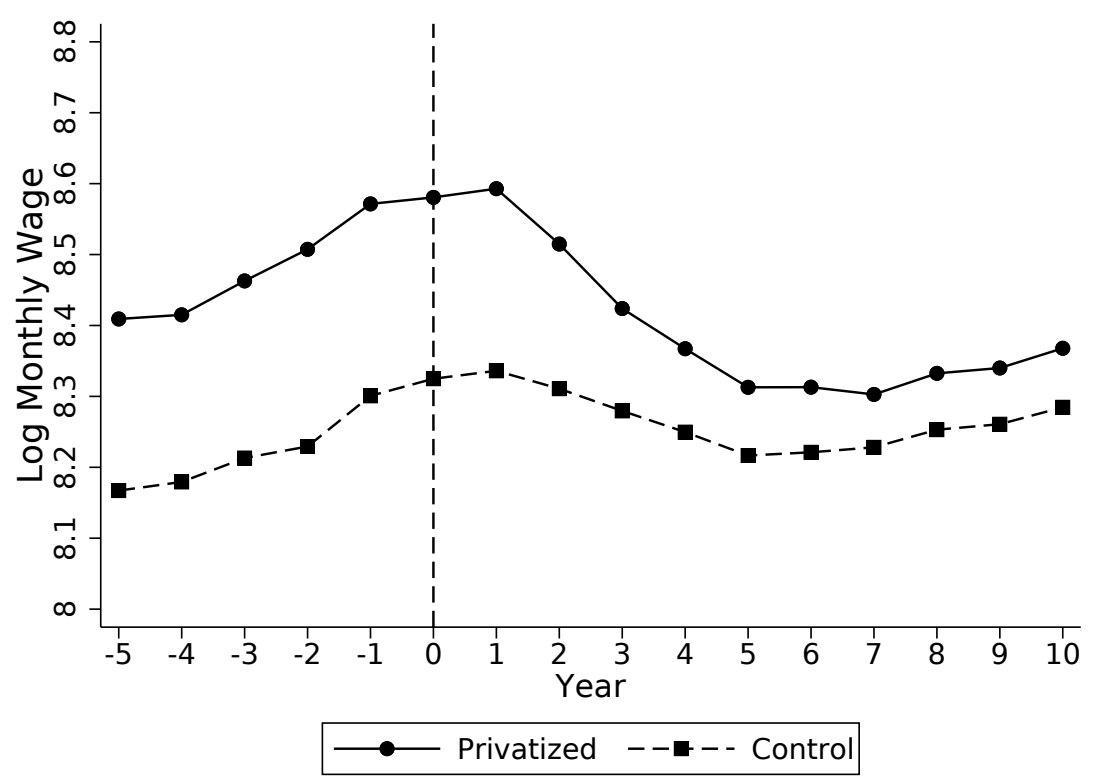

Panel B: Control Group: Never-privatized SOE Workers

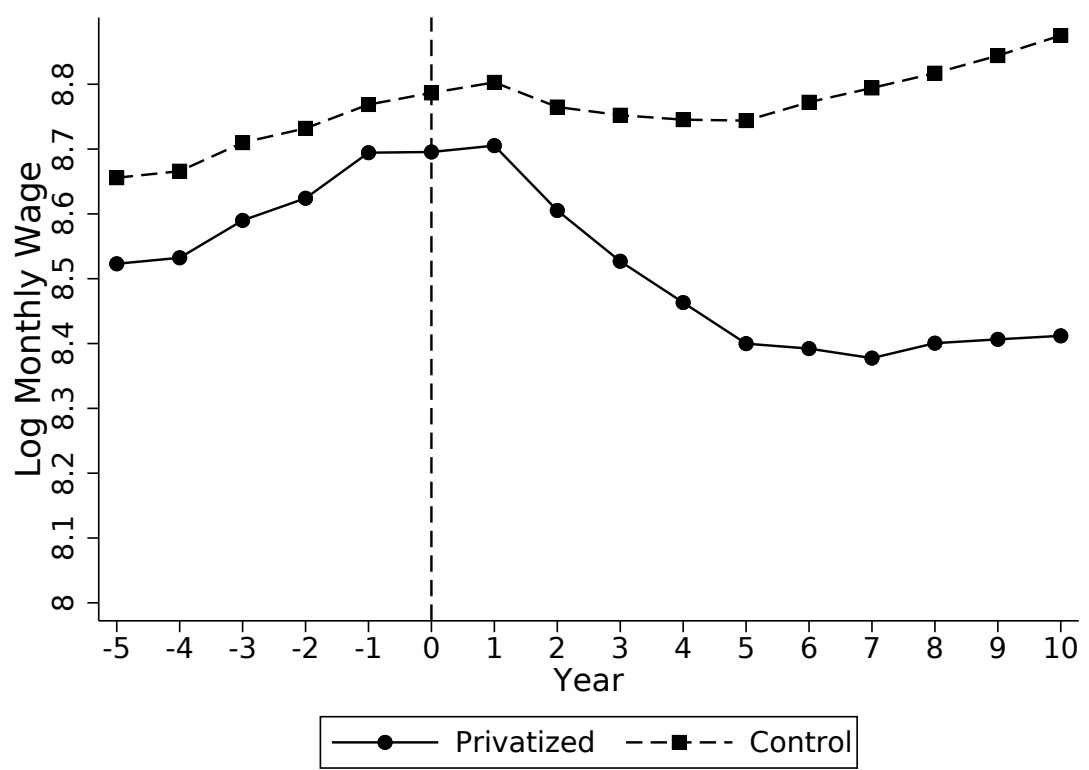

Note: This figure displays the average log monthly wage for workers in privatized establishments compared to a matched control group. The control group is constructed by matching workers in privatized SOEs to workers employed in either private-sector establishments (Panel A) or never-privatized SOEs (Panel B). The matching variables include two-digit occupation, two-digit industry and bins for age (where age bins are fiveyear increments). The panel is not balanced as individuals may transition into unemployment, retirement or the informal sector. The informal sector makes up roughly 40 percent of all employment in Brazil. 
Appendix Figure A2: Event-Study Estimates of the Effect of Privatization on Log Monthly Wages by Education

$$
y_{i t}=\sum_{k=-4}^{10} \delta_{k}\left(t=t^{*}+k\right) \text { Privatized }_{i}+\alpha_{i}+\gamma_{t}+x_{i t}^{\prime} \beta+\varepsilon_{i t}
$$

Panel A: All Workers

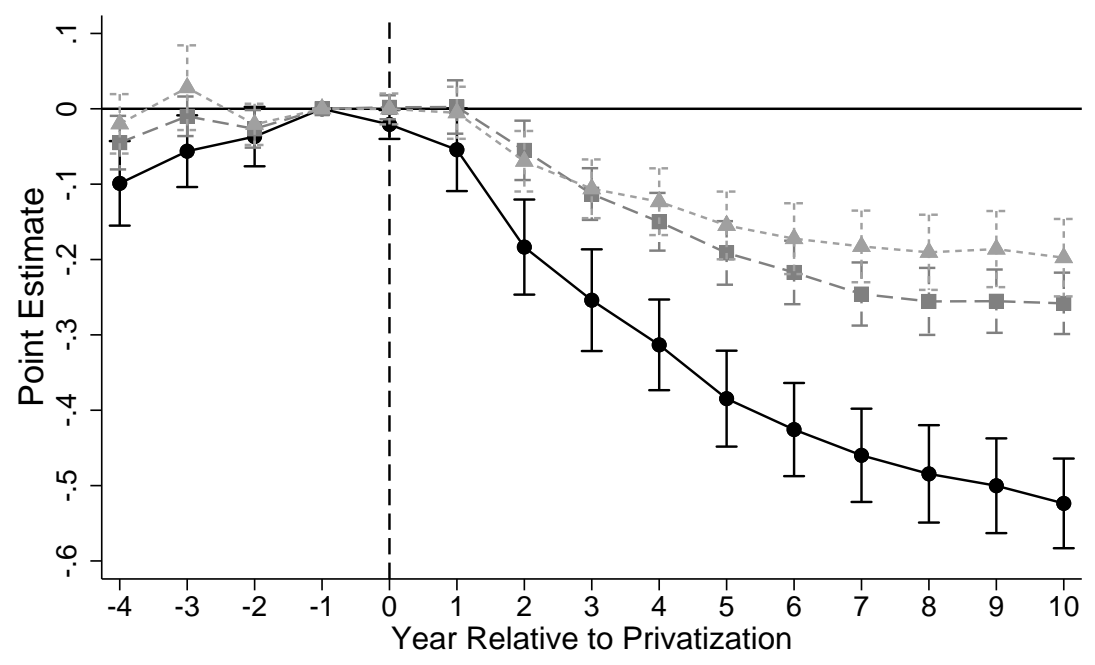

$\begin{array}{ll}\longrightarrow \longrightarrow & \text { No High School Degree } \quad--\square-- \text { High School Degree } \\ -\ldots-\cdots & \text { College Degree }\end{array}$

Panel B: Establishment Stayers

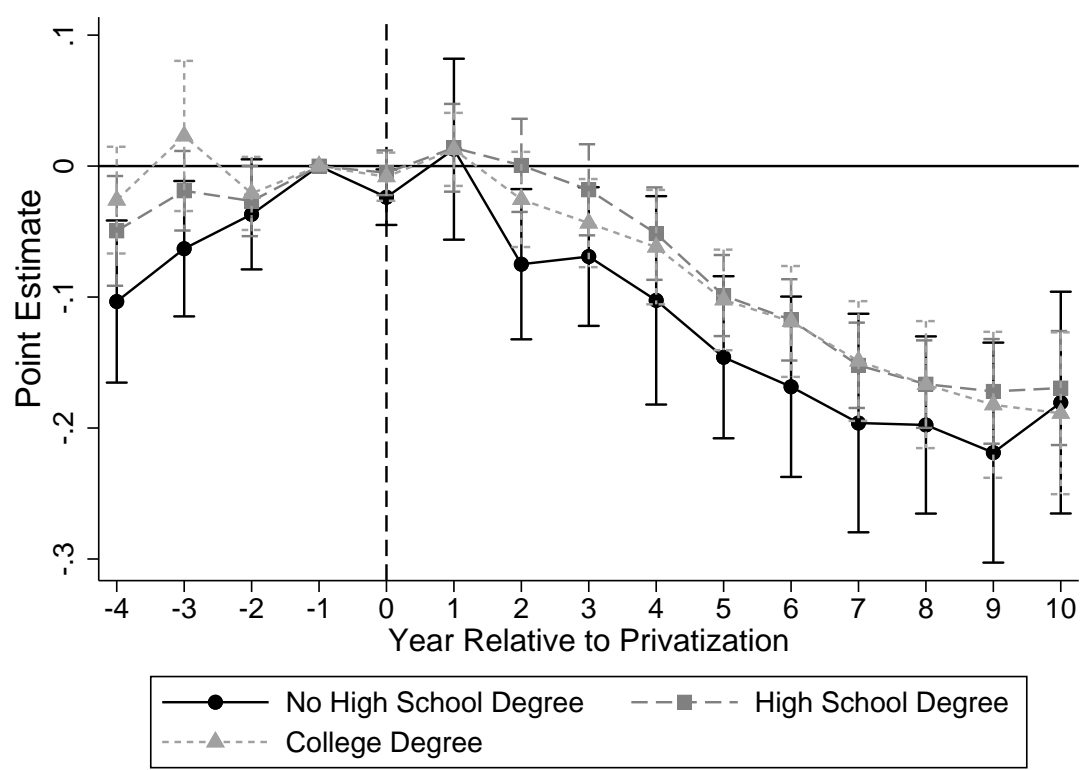

Note: This figure shows event-study estimates of the effect of privatization of log monthly wages separately by education. The omitted category is the year prior to the privatization event. The regressions control for individual fixed effects, year dummies, and a cubic in age. The control group is constructed by matching workers in privatized SOEs to workers employed in either private-sector establishments or never-privatized SOEs. The matching variables include two-digit occupation, two-digit industry and bins for age (where age bins are five-year increments). Standard errors are two-way clustered at the individual and establishment level. Panel A includes all workers while Panel B restricts to establishment stayers. Stayers are defined as workers in time $t$ who are employed in the same establishment as they were prior to privatization (i.e. year $t^{*}-1$ ). 
Appendix Figure A3: Event-Study Estimates of the Effect of Privatization on Formal Sector Employment by Education

$$
y_{i t}=\sum_{k=-4}^{10} \delta_{k}\left(t=t^{*}+k\right) \text { Privatized }_{i}+\alpha_{i}+\gamma_{t}+x_{i t}^{\prime} \beta+\varepsilon_{i t}
$$

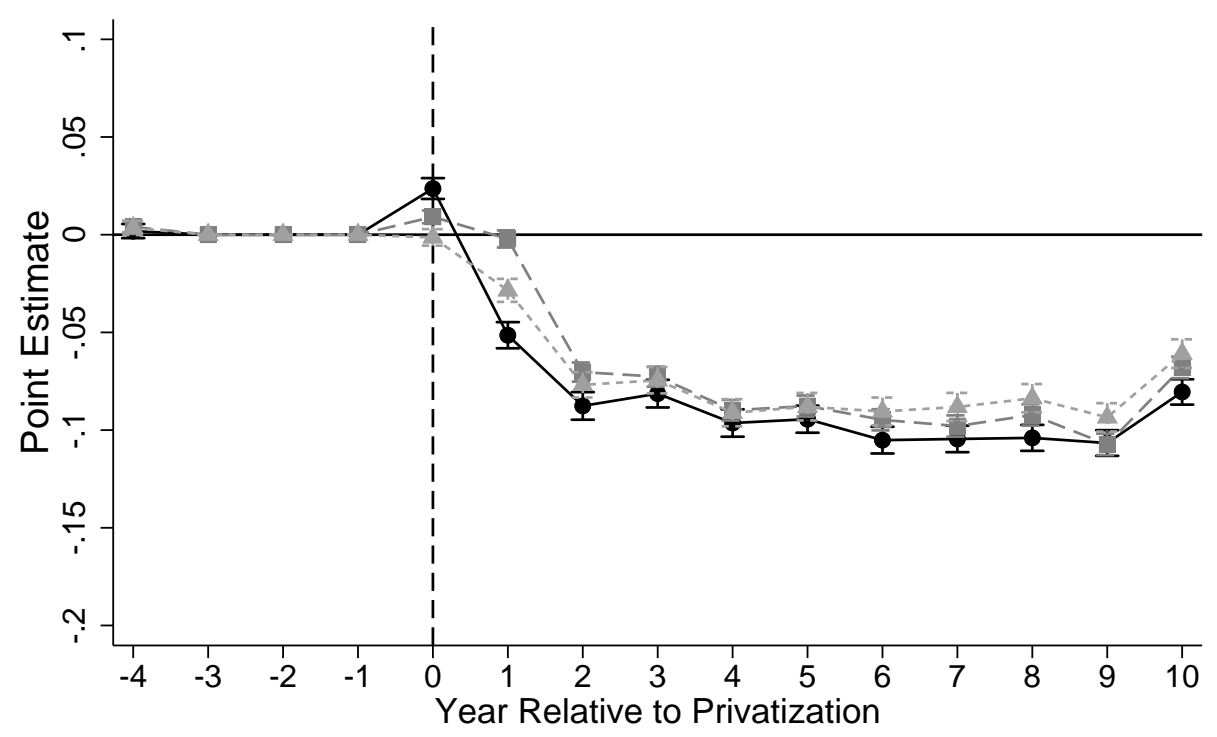

$$
\begin{array}{ll}
\longrightarrow- & \text { No High School Degree } \quad--1--- \text { High School Degree } \\
---\cdots-- & \text { College Degree }
\end{array}
$$

Note: This figure shows event-study estimates of the effect of privatization on the probability of formal sector employment. The omitted category is three years prior to the privatization event, given workers must be in the formal sector from years $t^{*}-2$ to $t^{*}-1$ to be in the analysis sample. The regressions control for worker fixed effects, year fixed effects and a cubic in age. The control group is constructed by matching workers in privatized SOEs to workers employed in either private-sector establishments or never-privatized SOEs. The matching variables include two-digit occupation, two-digit industry and bins for age (where age bins are fiveyear increments). Standard errors are clustered at the individual level. 
Appendix Figure A4: Histograms of Exposure Measures

Panel A: Histogram of Exposure

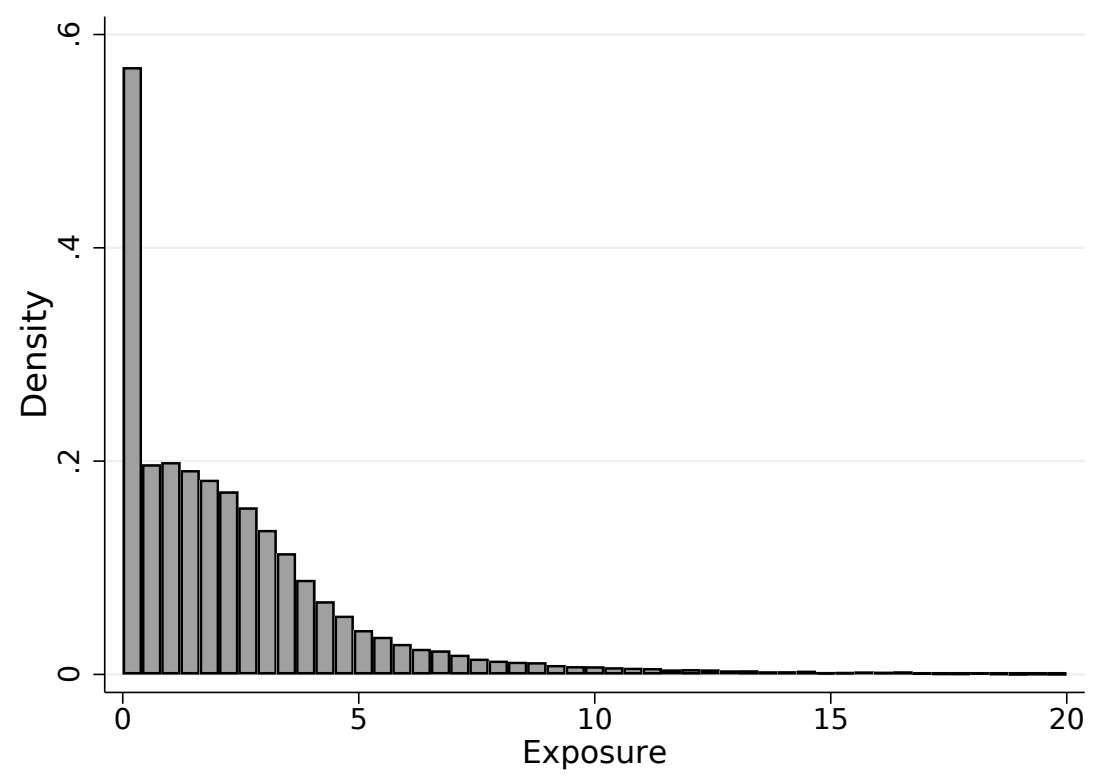

Panel B: Histogram of Ln(Exposure+1)

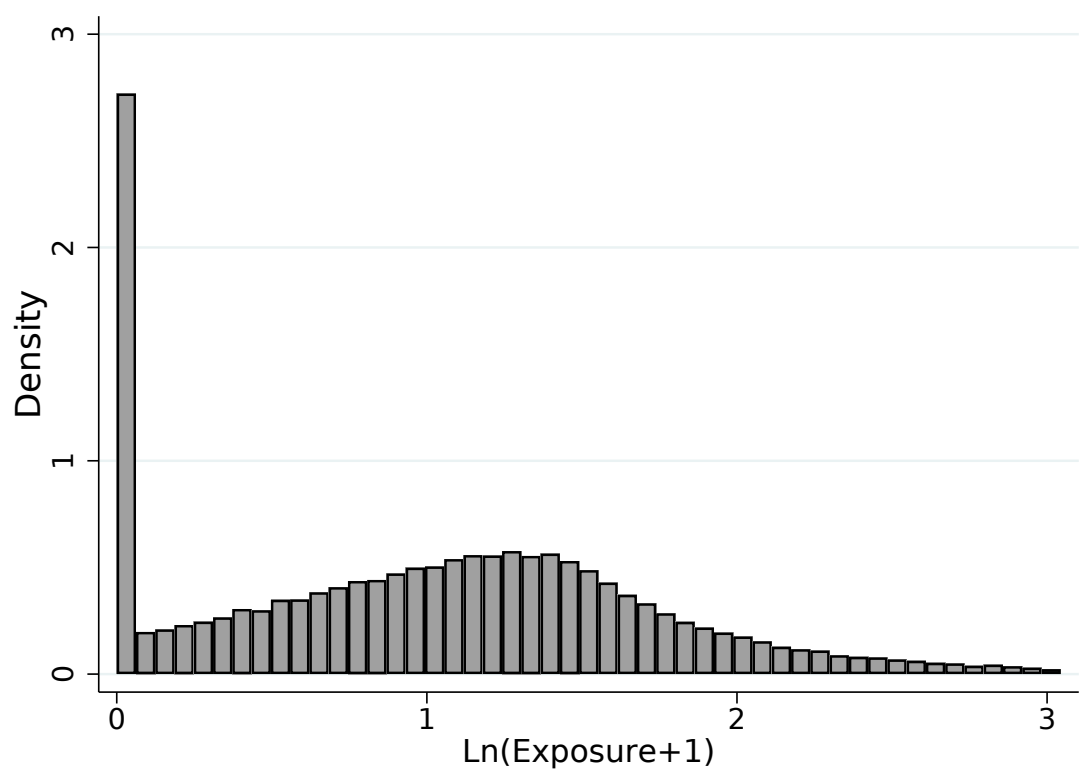

Note: This figure displays a histogram of exposure to privatization in Panel A and $\ln ($ Exposure +1$)$ in Panel B. Each observation is a labor market, where a labor market is defined as an occupation-by-microregion cell. This plot defines occupations at the five-digit level. 
Appendix Table A1: Robustness Results

\begin{tabular}{lcccccc}
\hline & $\begin{array}{c}\text { Private } \\
\text { Control }\end{array}$ & $\begin{array}{c}\text { SOE } \\
\text { Control }\end{array}$ & Winsorized & $\begin{array}{c}\text { Match } \\
\text { Earlier }\end{array}$ & $\begin{array}{c}\text { Add. Match } \\
\text { Variables }\end{array}$ & $\begin{array}{c}5 \text { digit } \\
\text { Occ./Sector }\end{array}$ \\
\cline { 2 - 7 } & $(1)$ & $(2)$ & $(3)$ & $(4)$ & $(5)$ & $(6)$ \\
\cline { 2 - 7 } & \multicolumn{7}{c}{} & & & & \\
Panel A: Effect of privatization on all workers & & & & & \\
Post Short-run & -0.032 & -0.056 & -0.048 & -0.047 & -0.023 & -0.050 \\
& $(0.015)$ & $(0.015)$ & $(0.014)$ & $(0.017)$ & $(0.008)$ & $(0.014)$ \\
Post Long-run & -0.154 & -0.258 & -0.203 & -0.226 & -0.214 & -0.221 \\
& $(0.019)$ & $(0.024)$ & $(0.019)$ & $(0.023)$ & $(0.012)$ & $(0.021)$ \\
Avg. Outcome at $t=-1$ & 8.436 & 8.732 & 8.620 & 8.649 & 8.671 & 8.652 \\
Observations & $1,965,433$ & $2,686,613$ & $3,746,461$ & $3,101,673$ & 970,427 & $3,127,210$ \\
& & & & & & \\
Panel B: Effect of privatization on stayers & & & & & \\
Post Short-run & -0.000 & 0.002 & -0.001 & 0.005 & 0.011 & -0.013 \\
& $(0.012)$ & $(0.014)$ & $(0.010)$ & $(0.017)$ & $(0.007)$ & $(0.012)$ \\
Post Long-run & -0.057 & -0.120 & -0.090 & -0.109 & -0.119 & -0.127 \\
& $(0.019)$ & $(0.019)$ & $(0.014)$ & $(0.021)$ & $(0.012)$ & $(0.016)$ \\
Avg. Outcome at $t=-1$ & 8.436 & 8.732 & 8.620 & 8.649 & 8.671 & 8.652 \\
Observations & $1,288,697$ & $1,799,471$ & $2,437,597$ & $2,095,286$ & 663,911 & $2,104,587$ \\
\hline Worker FE & Yes & Yes & Yes & Yes & Yes & Yes \\
Time FE & Yes & Yes & Yes & Yes & Yes & Yes \\
Demographics & Yes & Yes & Yes & Yes & Yes & Yes \\
\hline
\end{tabular}

Note: This table presents difference-in-differences estimates of the effect of privatization on workers' wages. Column 1 matches workers in privatized firms to workers in private-sector firms. Column 2 matches workers in privatized firms to workers in neverprivatized SOEs. Column 3 uses the main control samples, which allows workers to be matched to either a private-sector establishment or an SOE, and winzorizes log wages at the bottom 5 percentiles and the top 5 percentiles. Column 4 matches workers two years prior to privatization rather than one year prior to privatization. Column 5 adds microregion and bins for firm size to the coarsened-exact-matching algorithm. Column 6 matches on five-digit occupation and sector rather than two-digit occupation and sector. The short-run effect is equal to the effect of privatization in the four years following privatization. The long-run effect is equal to the effect of privatization in years five through ten following privatization. Panel A includes all workers while Panel B restricts to establishment stayers which are defined as workers in time $t$ who are in the same firm as they were prior to privatization (i.e. year $\left.t^{*}-1\right)$. Standard errors are two-way clustered by worker and establishment. 


\section{Appendix Table A2: Informal Sector Wage Penalty}

\begin{tabular}{lcc}
\hline & $\begin{array}{c}\text { All } \\
\text { Sectors }\end{array}$ & $\begin{array}{c}\text { Privatized } \\
\text { Sectors }\end{array}$ \\
\cline { 2 - 3 } Informal & $(1)$ & $(2)$ \\
\cline { 2 - 3 } Union & -0.324 & -0.264 \\
& $(0.001)$ & $(0.011)$ \\
Education (Years) & 0.099 & 0.136 \\
& $(0.002)$ & $(0.008)$ \\
Average outcome & 0.044 & 0.078 \\
Informality rate & $0.000)$ & $(0.001)$ \\
Observations & 830,420 & 6.904 \\
R Squared & 0.646 & 0.139 \\
Year FE & Yes & Yes \\
Sector FE & Yes & Yes \\
Occupation FE & Yes & Yes \\
State FE & Yes & Yes \\
Demographics & Yes & Yes \\
\hline
\end{tabular}

Note: This table presents OLS estimates of the informal sector wage penalty. Data is from the Brazilian National Household Survey, years 2002-2009. Additional demographic covariates include gender, withinjob tenure, number of jobs held, and a cubic in age. Heteroskedastic-robust standard errors are presented in parentheses. 
Appendix Table A3: The Effect of Privatization on Average Log Wages and Log Employment

\begin{tabular}{|c|c|c|c|}
\hline & $\begin{array}{c}\text { Avg. Log } \\
\text { Wage }\end{array}$ & $\begin{array}{l}\text { Avg. Entrant } \\
\text { Log Wage }\end{array}$ & $\begin{array}{l}\text { Log } \\
\text { Emp } \\
\end{array}$ \\
\hline & (1) & (2) & (2) \\
\hline Event time $=-4$ & $\begin{array}{c}0.002 \\
(0.026)\end{array}$ & $\begin{array}{c}0.122 \\
(0.042)\end{array}$ & $\begin{array}{c}0.109 \\
(0.022)\end{array}$ \\
\hline Event time $=-3$ & $\begin{array}{c}0.006 \\
(0.021)\end{array}$ & $\begin{array}{c}0.171 \\
(0.034)\end{array}$ & $\begin{array}{c}0.066 \\
(0.016)\end{array}$ \\
\hline Event time $=-2$ & $\begin{array}{c}0.005 \\
(0.016)\end{array}$ & $\begin{array}{c}0.113 \\
(0.030)\end{array}$ & $\begin{array}{c}0.042 \\
(0.012)\end{array}$ \\
\hline Event time $=0$ & $\begin{array}{c}0.000 \\
(0.011)\end{array}$ & $\begin{array}{r}-0.098 \\
(0.041)\end{array}$ & $\begin{array}{r}-0.020 \\
(0.012)\end{array}$ \\
\hline Event time $=1$ & $\begin{array}{r}-0.057 \\
(0.025)\end{array}$ & $\begin{array}{r}-0.177 \\
(0.063)\end{array}$ & $\begin{array}{r}-0.207 \\
(0.022)\end{array}$ \\
\hline Event time $=2$ & $\begin{array}{r}-0.147 \\
(0.033)\end{array}$ & $\begin{array}{c}-0.349 \\
(0.053)\end{array}$ & $\begin{array}{c}-0.391 \\
(0.027)\end{array}$ \\
\hline Event time $=3$ & $\begin{array}{r}-0.134 \\
(0.023)\end{array}$ & $\begin{array}{r}-0.231 \\
(0.067)\end{array}$ & $\begin{array}{r}-0.419 \\
(0.035)\end{array}$ \\
\hline Event time $=4$ & $\begin{array}{r}-0.140 \\
(0.037)\end{array}$ & $\begin{array}{r}-0.166 \\
(0.062)\end{array}$ & $\begin{array}{c}-0.594 \\
(0.041)\end{array}$ \\
\hline Avg. Outcome at $t=-1$ & 8.473 & 8.606 & 2.284 \\
\hline Observations & 22,040 & 15,047 & 22,040 \\
\hline Establishment FE & Yes & Yes & Yes \\
\hline Year FE & Yes & Yes & Yes \\
\hline
\end{tabular}

Note: This table presents event-study estimates of the effect of privatization on average log wages (Column 1) average log entrant wages (Column 2) and log employment (Column 3). The sample is restricted to establishments which are privatized at some point between 1996 and 2000. Standard errors are clustered at the establishment level. 


\section{Appendix Table A4: Effect of Privatization on AKM Wage Premiums}

\begin{tabular}{cccc}
\hline \multirow{5}{*}{ Short-run } & No HS & HS & College \\
& Degree & Degree & Degree \\
\cline { 2 - 4 } & $(1)$ & $(2)$ & $(3)$ \\
\cline { 2 - 4 } Long-run & -0.045 & -0.065 & -0.076 \\
& $(0.002)$ & $(0.002)$ & $(0.002)$ \\
& -0.121 & -0.101 & -0.098 \\
Observations & $(0.006)$ & $(0.004)$ & $(0.006)$ \\
\hline
\end{tabular}

This table estimates an AKM model with worker fixed effects, establishment fixed effects, a cubic in age interacted with year dummies, as well as in indicator for the short-run effect of privatization which is equal to one in the four years after privatization and a long-run effect of privatization which is equal to one if it has been more than four years since privatization. The sample includes all years between 1993-2004. Homoscedasticstandard errors are reported in parentheses. 


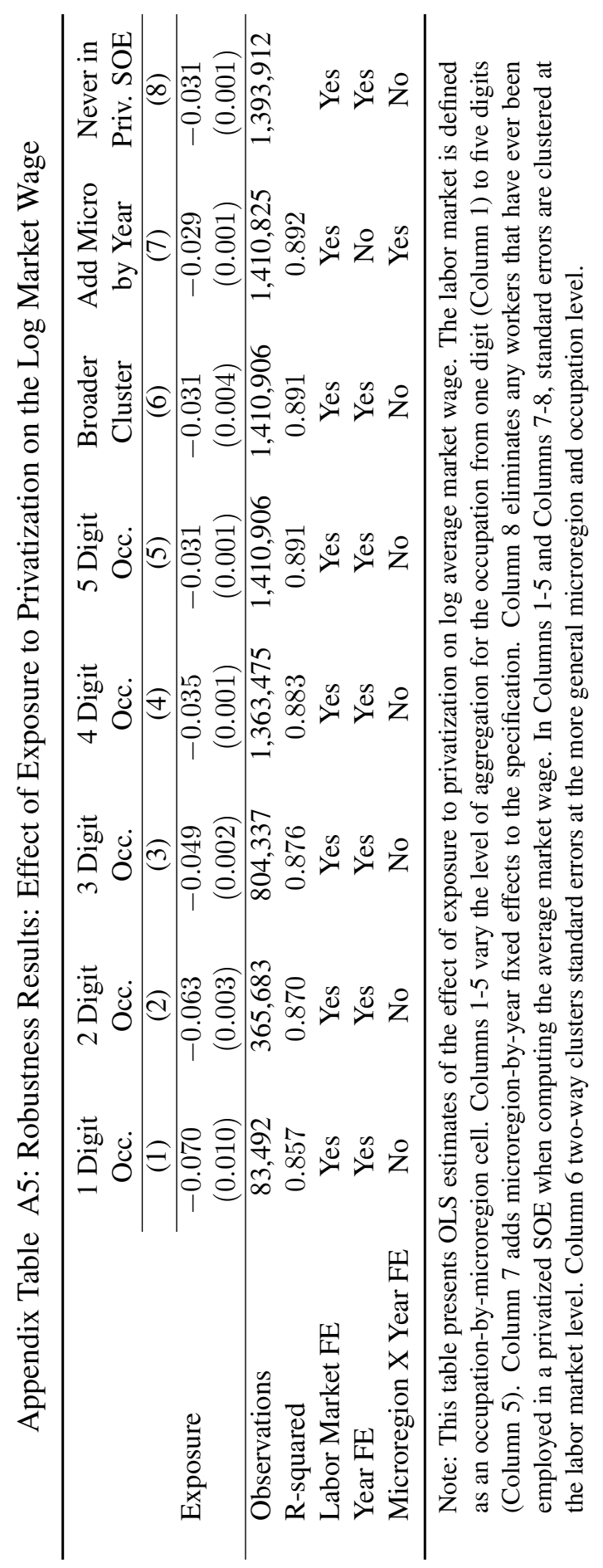




\title{
Online Appendix B: Data Appendix
}

\author{
A. Overview of RAIS data
}

The Relação Anual de Informações Sociais (RAIS) is an employer-employee matched dataset which includes information on all workers and establishments in the formal sector of Brazil. The main use of the RAIS is to compute federal wage-supplements (Abono Salarial). While not reporting can in theory result in fines, these fines are rarely issued in practice. However, workers and establishments are incentivized to provide accurate wage information given the federal public wage-supplement is based on the wage reported in the RAIS.

\section{B. Sample Selection}

In the RAIS, workers are identified by an individual-specific PIS (Programa de Integração Social), a unique time-invariant worker identifier similar to a social security number. I follow Menezes-Filho and Muendler (2011) and drop workers with PIS identifiers less than 11 digits, as these are not valid identifiers. Errors in worker identifiers may be caused by (1) bad compliance and bookkeeping errors or (2) to allow workers to withdraw from their severance account through fake layoffs and rehires.

Most of the analysis (with the exception of the AKM models), is restricted to either state-owned enterprises or private-sector establishments. This eliminates public administration workers or workers for non-profits and charities. The distinction between SOEs and public administration is important given public administration workers are employed under different contracts than workers in SOEs or private-sector establishments. The public administration contract includes restrictions on firing employees while contracts for workers in SOEs do not.

\section{Variable Definitions}

PIS: A PIS is a worker identifier that is unique to a given worker over time.

CNPJ: The CNJP is an establishment-level identifier issued by the Brazilian tax authority which is unique to a given establishment over time. The first eight digits of the CNPJ corresponds to the firm of the establishment, while the last six correspond to the establishment within the firm.

Education: The RAIS records education at eight different categories. I re-code these variables to four categories: (1) Less than High-School (2) High-School Graduate (3) College Graduate. Education for an individual worker is set to the modal value of education for the worker over the sample period.

Occupation: Occupations are defined by the Classificação Brasileira de Ocupações (CBO) into 2,355 distinct groups. To increase the number of matches, I use subgroups consisting of the first two digits of the five-digit occupation code, which reduces the number of distinct occupations down to 84 .

Sector: Sectors are reported under the CNAE four-digit classification (Classificação Nacional de Atividade Econômica) for 654 industries. I aggregate sectors to the two-digit level in the paper, unless specified otherwise. 
Wage: Wage refers to total payments, including regular salary payments, holiday bonuses, performancebased and commission bonuses, tips, and profit sharing agreements, divided by total months worked during the year for that employer. Payments that are not considered part of the wage include severance payments for layoffs and indemnity pay for maternal leave. Wages in the dataset are reported in terms of multiples the monthly minimum wage, which are then converted to real earnings using inflation adjustments available from Brazil's Institute of Applied Economic Research (IPEA) ${ }^{35}$

Legal Nature: An establishment is issued a tax identifier (CNPJ) along with a legal form. There are many legal forms possible. For the purposes of this paper, any legal form which indicates at least partial state ownership is designated as an SOE. This differs from public administration establishments which have different legal forms. Legal form is only included in the RAIS from 1995 onwards. When a given establishment is privatized, the legal form changes and is updated in the Brazilian business register, but the tax identifier does not change. 36

Microregion: Microregions in Brazil are defined by the Brazilian Statistical Agency (IBGE). Microregions group together clusters of contiguous municipalities with similar geographic and economic characteristics, similar to commuting zones in the United States.

\section{Overview of PNAD}

The Brazilian National Household Survey, Pesquisa Nacional por Amostra de Domicìlios (PNAD) is a survey conducted by the Brazilian statistical agency IBGE, since 1981. From 2001 onward, the Brazilian microdata from the PNAD is available online at the IBGE website 37 The PNAD uses the same sector classification (CNAE) and occupation classification (CBO) as the RAIS data. Most importantly for this project, the PNAD also contains a question about whether the worker is employed in the formal or informal sector, allowing to estimate the informal-sector wage penalty controlling for both the sector of employment as well as the occupation of the worker.

\footnotetext{
${ }^{35}$ The early 1990s was a period of rapid inflation in Brazil. By 1995, price stabilization had succeeded due to the Plano Real reform which was implemented in August 1994.

${ }^{36}$ For a searchable online database of the business register see http://www.receita.fazenda.gov.br

${ }^{37}$ See website:https://ww2.ibge.gov.br. A package in STATA, called Data Zoom, is made available by the Department of Economics at PUC-Rio which standardizes questions across years.
} 